\title{
Labor Earnings Respond Differently to Income- Tax and to Payroll-Tax Reforms
}

\author{
Etienne LEHMANN, CREST (ENSAE) ${ }^{+}$ \\ François MARICAL, CREST (INSEE) ${ }^{\times}$ \\ Laurence RIOUX, CREST (INSEE) ${ }^{\infty}$
}

February 11, 2011

\begin{abstract}
We estimate the responses of gross labor income with respect to marginal and average net-oftax rates in France over the period 2003-2006. We exploit reforms of the income and payroll tax schedules that affect individuals earning less than twice the income of a full-time minimum wage worker. Our estimate for the elasticity with respect to the marginal income net-of-tax rate is around 0.3 while we find no response to changes in the marginal payroll net-of-tax rate. Elasticities with respect to the average tax rates are not significant for the income tax schedule while it is close to -1 for the payroll tax schedule. A possible explanation is a rigidity of the hourly posted wage, together with labor supply responses, casting doubts about public finance analysis that assume perfect competition on the labor market.
\end{abstract}

Keywords: Labor Earnings, Payroll Tax, Income Tax

JEL: H24, H31, J22, J38

\footnotetext{
* We thank Valérie Albouy, Bruno Crépon, Guy Laroque and participants at internal seminars at CREST for helpful remarks and comments. Remaining errors are ours.

+ Corresponding author: CREST - INSEE, Timbre J360, 15 Boulevard Gabriel Péri, 92245 Malakoff Cedex, France. Email: Etienne.Lehmann@ensae.fr. Etienne Lehmann is also extramural fellow of IRES Université Catholique de Louvain (Belgium) and research fellow at IZA (Bonn, Germany), IDEP (Marseilles, France) and CESifo (Munich, Germany).

× François Marical, Francois.Marical@developpement-durable.gouv.fr

$\infty$ Laurence Rioux, Laurence.Rioux@insee.fr
} 


\section{Introduction}

Labor income taxation is composed of several distinct schedules. According to the OECD tax database, ${ }^{1}$ the total tax wedge for an average-wage worker amounts to $29.4 \%$ of labor costs to the employer in the U.S. in 2009. This tax wedge can be decomposed into $7.7 \%$ for transfers to the "central government", $5.7 \%$ for transfers to "sub-central" governments, and $15.9 \%$ for "social security contributions". In France at the same time, the total tax wedge for an average-wage earner amounts to $49.2 \%$, with only $9.8 \%$ for transfers to the central government and $39.4 \%$ for social security contributions. Whether or not earnings respond identically to the different schedules is crucial to determine which type of tax should be used to finance public expenditures, including social security expenses and redistribution. In this work, we focus on the relative responsiveness of labor earnings to payroll (social security contributions) versus income taxation.

The existing literature is interested in the earnings responses to either the income tax or the payroll tax schedules. ${ }^{2}$ There exist at least two reasons why it never simultaneously considers the responses to both schedules. A first one is the absence of simultaneous reforms to both schedules for similar individuals over the same period. Second, most common models of the labor markets predict identical earnings responses to payroll and to income tax schedules. In contrast to the literature, we exploit a series of reforms to both the income and the payroll tax schedules that occurred in France over 2003-2006. On the one hand, the Prime pour l'Emploi, a tax credit for low-wage earners, has been substantially extended, the maximum amount of benefits being almost doubled from 2003 to 2006. On the other hand, the period saw deep changes in programs aiming at stimulating the hiring of low skilled workers through reductions in employers' payroll taxes for jobs paid close to the Minimum Wage level (see e.g. Kramarz and Philippon (2001)). Due to the partial implementation of the 35-hour workweek, two distinct schedules for the reduction in employers' payroll taxes for low-paid jobs coexisted in 2003, depending on whether or not the firm had moved to the 35-hour workweek. The two schedules have been reformed since 2003 to converge to a single one in July $1^{\text {st }} 2005$. The extension of the income tax credit combined with the convergence of the two schedules of reduction in payroll taxes generates a rich set of changes in both the income and the payroll tax schedules for workers earning less than 2.1 times the minimum wage, which represent about half of the employed labor force. This gives us the very unlikely opportunity to assess the relative responsiveness of labor earnings to income tax and payroll tax schedules.

\footnotetext{
${ }^{1}$ Authors' calculations from OECD tax data base available at http://www.oecd.org/dataoecd/44/3/1942514.xls

${ }^{2}$ Most of the papers focus on the distortions induced by income taxes (e.g. Feldstein (1995), Auten and Caroll (1999), Gruber and Saez (2002), Saez (2003), Blomquist and Selin (2010), Cabannes, Houdré and Landais (2011) among others. Another strand of the literature estimate the effects of payroll tax reforms (e.g. Gruber (1997), Kugler and Kugler (2009), and Saez, Matsaganis and Tsakloglu (2010) among others).
} 
The dataset we use is the Enquête Revenus Fiscaux, which combines income tax records from the fiscal administration with the French Labor Force Survey (Enquête Emploi hereafter LFS). Whereas the information contained in income tax records allows us to compute the income tax schedule (including the tax credit for low-wage earners), it is insufficient for the payroll tax schedule. However, income tax records matched to the LFS provide all the information necessary to reconstruct the payroll tax. In particular, the labor market history and the usual weekly working time enable us to infer a monthly wage and an hourly wage, which are the basic inputs for calculating payroll taxes. Payroll taxes also depend on the size of the firm and on the type of occupation, which are provided by the LFS. Finally, we are able to infer whether the firm has moved to the 35-hour workweek, which determines which payroll tax schedule applies. To the best of our knowledge, this is the first work that uses income tax records matched to the Labor Force Survey to investigate the responsiveness of labor income to both income and payroll tax reforms.

We estimate the (pre-tax) labor income responses to the marginal and average net-of-tax rates ${ }^{3}$ for both schedules. We find a significant elasticity (around 0.3) of labor earnings with respect to the marginal income net-of-tax rate. By contrast, the elasticity of labor earnings with respect to the marginal payroll net-of-tax rate is statistically insignificant and close to zero. This leads us to conclude that labor earnings respond differently to payroll taxes and income taxes. We also find different income effects for income taxes and payroll taxes. The elasticity with respect to the average payroll net-of-tax rate does not differ significantly from minus one, while the elasticity with respect to the average income net-of-tax rate is not significant.

These results contradict the predictions of the most common models of the labor markets according to which gross labor income should respond identically to payroll and to income tax schedules. Our preferred interpretation for our findings is the rigidity of the hourly posted wage (i.e. gross wage minus employer payroll taxes) over this period, combined with significant labor supply responses to the income tax schedule. This in particular suggests that, at least in the short-run, financing social security expenses and redistribution through payroll taxes is much less distortive than through income taxes (e.g. through the extension of the tax credit for low-wage earners). Our results also imply that in France, reducing employer payroll taxes for low paid jobs actually decreases the labor cost to the employer around the minimum wage level, without affecting the posted wage. Hence, we do not find that reductions of employers' payroll tax for low paid jobs have exacerbated a "low wage trap" in France. ${ }^{4}$ Finally, the plausibility of posted wage rigidity suggests that the assumption of a competitive labor market might be inadequate for applied public finance, at least for economies such as France where the labor market is highly regulated. As the latter assumption is made in a large part

\footnotetext{
${ }^{3}$ The marginal (respectively average) net-of-tax rate is equal to one minus the marginal (average) tax rate.

${ }^{4}$ See Aeberhardt and Sraer (2009), Bunel, Gilles, and L'Horty (2009), and Lhommeau and Remy (2009).
} 
of the optimal income tax literature (e.g. Mirrlees (1971)), one can question the relevance of the normative predictions derived by these models.

A large strand of the literature is interested in the response of taxable income to the marginal net-of-tax rate, following the idea of Lindsey (1987) and Feldstein (1995) that this elasticity summarizes all the deadweight losses due to taxation. We here compare our results with the main conclusions of this literature. i) The literature considers that the elasticity is hard to identify, in particular because of the difficulties to control for non-tax related changes in income. We better account for these changes by using additional control variables provided by the Labor Force Survey. ii) At a first look, our estimate of 0.3 for the elasticity with the marginal income net-of-tax rate belongs to the range of reliable values found in the literature (between 0.12 and 0.4 according to Saez, Slemrod and Giertz (2010)). However, we here estimate the response of gross wages (labor cost) while most works are interested in the responses of taxable incomes. Restricting the comparison to taxable labor income, our estimate is consistent with that of Blomquist and Selin (2010), who find significant responses, whereas differing from Saez (2003) who suggests that labor earnings do not significantly respond to taxation. iii) The existing literature suggests that the elasticity is presumably much higher for top income earners. However, we obtain a significant elasticity of labor earnings with respect to the marginal income net-of-tax rate by using reforms that affect individuals below the median of the wage distribution. iv) The literature that focuses on the responses to payroll taxes generally found no effect of marginal tax rates unlike the literature on income taxation. Our results suggest that these findings are more robust than it may appear at a first sight $v$ ) Finally, our result that labor earnings are insensitive to the marginal payroll tax rate is consistent with those found by different studies using French data. The novelty is that we exhibit simultaneously the unresponsiveness of posted wages to payroll taxes and their responsiveness to income taxes.

The paper is organized as follows. Section II defines the different elasticity concepts and discusses theoretically whether labor earnings should respond identically to income taxes and payroll taxes. In section III, we present our empirical strategy and discuss the identification. Section IV describes the dataset used, which combines income tax records with the Labor Force Survey. In section $\mathrm{V}$, we detail the institutional backgrounds and expose the main reforms that took place in France over the 2003-2006 period. Section VI presents results on the respective effects of payroll and income taxes on labor earnings, and the last section concludes. 


\section{Theoretical backgrounds}

\section{II.1 Definitions}

Because of the existence of taxes and transfers, the (annual) net wage $c$ that a worker can consume differs from the gross wage $w$ paid by her employer. In most countries, labor earnings taxation can be decomposed into social security contributions or payroll taxes (that finance social security programs such as PAYG pensions, health insurance, unemployment insurance, etc.) and taxes to governments or income taxes.

The payroll tax is a function of the gross wage and is denoted with a superscript $P$. We denote by $z$ the posted wage, defined as the gross wage minus the payroll tax. On a linear part of the payroll tax schedule, we get:

$$
Z=\tau^{P} w+R^{P}
$$

where $\tau^{P}$ denotes the marginal payroll net-of-tax rate and $R^{P}$ is the virtual posted income. We denote by $\rho^{P}=\frac{Z}{w}=\tau^{P}+\frac{R^{P}}{w}$ the average payroll net-of-tax rate.

The income tax schedule, denoted with a superscript $I$, consists of income tax per se and of tax credits providing income subsidies to low-wage earners (e.g. Earned Income Tax Credit in the U.S., Prime Pour l'Emploi in France, etc.). The income tax is a function of the posted wage z. On a linear part of the income tax schedule, the net wage $c$ equals the posted wage minus income taxes through:

$$
C=\tau^{I} Z+R^{I}
$$

where $\tau^{I}$ denotes the marginal income net-of-tax rate and $R^{I}$ is the virtual net income. We denote by $\rho^{I}(z)=\frac{C}{Z}=\tau^{I}+\frac{R^{I}}{Z}$ the average income net-of-tax rate. Combining Equations (1) and (2) gives the budget constraint:

$$
C=\tau^{I} \tau^{P} w+\tau^{I} R^{P}+R^{I}
$$

We thus define the global marginal net-of-tax rate as $\tau=\tau^{P} \tau^{I}$, the global virtual income as $R=\tau^{I} R^{P}+R^{I}$, and the global average net-of-tax rate $c / w$ as $\rho=\rho^{P} \rho^{I}$. 
The three wages $w, z$ and $c$ are endogenous and may depend on each of the four tax parameters $\tau^{I}, \tau^{P}, R^{I}$ and $R^{P}$. More precisely, let assume that the gross wage $w$ is determined by a function denoted $W\left(\tau^{\mathrm{I}}, \tau^{P}, R^{I}, R^{P}\right)$. Partial derivatives of the function $W$ then define a first set of behavioral parameters:

$$
\frac{\Delta w}{w}=\left(\frac{\tau^{P}}{w} \frac{\partial W}{\partial \tau^{P}}\right) \frac{\Delta \tau^{P}}{\tau^{P}}+\left(\frac{\tau^{I}}{w} \frac{\partial W}{\partial \tau^{I}}\right) \frac{\Delta \tau^{I}}{\tau^{I}}+\left(\frac{\partial W}{\partial R^{P}}\right) \frac{\Delta R^{P}}{w}+\left(\frac{\partial W}{\partial R^{I}}\right) \frac{\Delta R^{I}}{w}
$$

For $j=I, P$, the elasticity $\left(\tau^{j} / w\right)\left(\partial W / \partial \tau^{j}\right)$ captures the change in gross wages generated by a tax reform that not only modifies the slope of the budget constraint (3), but also the amount of tax paid. This is the reason why it is referred to as the uncompensated elasticity with respect to the marginal $j$ net-of-tax rate. However, the theory of optimal taxation puts more emphasis on compensated elasticities. These ones capture the response of gross wages to tax reforms that modify the slope of the tax schedule while leaving unchanged the amount of tax paid at the pre-reform earnings level. ${ }^{5}$ Formally, let $w^{*}$ and $z^{*}$ denote respectively the initial gross and posted wages, with $Z^{*}=\tau^{P} W^{*+} R^{P}$. Then, the compensated elasticity with respect to the marginal payroll (respectively income) net-of-tax rate $\beta_{\tau}^{P}$ (respectively $\beta_{\tau}^{I}$ ) captures the effect on gross wages of a payroll (respectively income) tax reform that varies the virtual posted income $R^{P}$ (respectively virtual net income $R^{I}$ ) in such a way that the amount of payroll (resp. income) tax paid at $w^{*}$ (resp. at $z^{*}$ ) is kept unchanged, i.e. $\Delta R^{P}=-w^{*} \Delta \tau^{P}$ (resp. $\Delta R^{I}=-z^{*} \Delta \tau^{I}$ ). The compensated elasticities are thus given by the "Slutsky-alike" equations:

$$
\beta_{\tau}^{P}=\left(\frac{\tau^{P}}{w^{*}} \frac{\partial W}{\partial \tau^{P}}\right)-\tau^{P} \frac{\partial W}{\partial R^{P}} \quad \text { and } \quad \beta_{\tau}^{I}=\left(\frac{\tau^{I}}{w^{*}} \frac{\partial W}{\partial \tau^{I}}\right)-\tau^{I} \rho^{P} \frac{\partial W}{\partial R^{I}}
$$

For a given level of the gross wage $w^{*}$, the change $\Delta \rho^{P}$ in the average payroll net-of tax rate equals $\Delta \tau^{\mathrm{P}}+\left(\Delta R^{\mathrm{P}} / w^{*}\right)$, while the change $\Delta \rho^{I}$ in the average income net-of tax rate equals $\Delta \tau^{\mathrm{I}}+\left(\Delta R^{\mathrm{I}} / \mathrm{z}^{*}\right)$ $\left(R^{I} / w^{*}\right)\left(\Delta \rho^{P} /\left(\rho^{P}\right)^{2}\right)$. Combining (4) and (5) then leads to (See Appendix A.1):

$$
\frac{\Delta w}{w^{*}}=\beta_{\tau}^{p} \frac{\Delta \tau^{P}}{\tau^{p}}+\beta_{\tau}^{I} \frac{\Delta \tau^{I}}{\tau^{I}}+\beta_{\rho}^{p} \frac{\Delta \rho^{P}}{\rho^{P}}+\beta_{\rho}^{I} \frac{\Delta \rho^{I}}{\rho^{I}}
$$

\footnotetext{
${ }^{5}$ For instance, when the choice of $w$ reflects a labor supply decision in a competitive labor market and the labor demand is infinitely elastic, the compensated elasticity captures only substitution effects while the uncompensated one captures both substitution and income effects. Then, the deadweight losses associated with taxation not being lump-sum are proportional to the compensated elasticity of the labor supply.
} 
where the elasticity $\beta_{\rho}^{P}$ (respectively $\beta_{\rho}^{I}$ ) with respect to the average payroll (respectively income) net-of-tax rate is defined by:

$$
\beta_{\rho}^{P}=\rho^{P}\left(\frac{\partial W}{\partial R^{P}}+\frac{R^{I}}{z^{*}} \frac{\partial W}{\partial R^{I}}\right) \quad \text { and } \quad \beta_{\rho}^{I}=\rho^{P} \rho^{I} \frac{\partial W}{\partial R^{I}}
$$

\section{II.2. Foundations}

In a large class of models of the labor market, the gross wage is determined by the maximization of an objective function that depends negatively on the labor cost $w$ to the firm and positively on the net wage $c$ paid to the worker. This objective takes the general form $U(c, w)$ with $U_{c}^{\prime}>0>U_{w}^{\prime}$. We henceforth refer to this class of models as the "benchmark" ones. The textbook labor supply framework is typically one of them. In this framework, a worker of productivity $p$ supplying $L$ units of labor earns a gross wage $w=p L$. If her preferences over consumption and labor supply are described by the utility function $u(c, L)$, with $u_{c}^{\prime}>0>u_{L}^{\prime}$, one can define function $U$ by $U(c, w) \equiv u(c, w / p)$. The objective $U$ is decreasing in the gross wage $w$ because earning a higher gross wage $w$ requires working more intensively (i.e. higher $L$ ). The monopoly union model (under right-tomanage) is also a benchmark model. If the union's objective over net wages $c$ and employment $L$ is described by $u(c, L)$ and if the labor demand is described by the decreasing function $L=l^{d}(w)$, then function $U$ is defined by $U(c, w) \equiv u\left(c, I^{d}(w)\right)$. Here, $U$ is decreasing in the gross wage because the labor demand depends negatively on the labor cost. Lastly, wage bargaining settings (Lockwood and Manning, 1993, Pissarides, 2000,...) are other examples of benchmark models. In these frameworks, function $U(c, w)$ is given by the generalized Nash product where the worker's (or union's) contribution to the Nash product is increasing in the net wage $c$, while the firm's contribution is decreasing in $w$, as higher gross wages lower profits. However, it is worth noting that, for the monopoly union model as well as for the wage bargaining model, the objective function takes the form $U(c, w)$ only if the wage setting concerns homogenous workers and firms, which implies that the wage and the tax schedules are unique. Hence, only bargaining models at the individual level (e.g. as in Mortensen and Pissarides, 1994) or at collective levels but for homogenous labor markets can be reduced to the maximization of this type of objective.

In any benchmark model, the gross wage is determined by the maximization of $U(c, w)$ subject to (3), the posted wage $z$ being an intermediate that is economically irrelevant. Formally, we have:

$$
w=\underset{w}{\arg \max } U(\tau w+R, w) \equiv \Omega(\tau, R)
$$


This implies that the various tax parameters influence the gross wage only through the global marginal net-of-tax rate, $\tau=\tau^{P} \tau^{I}$, and the global virtual income, $R=\tau^{I} R^{P}+R^{I}$. The function $W$ then verifies the following restriction:

$$
W\left(\tau^{I}, \tau^{P}, R^{I}, R^{P}\right)=\Omega\left(\tau^{I} \tau^{P}, \tau^{I} R^{P}+R^{I}\right)
$$

Let $\beta_{\tau}$ and $\beta_{\rho}$ define respectively the compensated elasticity with respect to the global marginal and average net-of-tax rates. Then applying the same Slutsky-alike decomposition as made in Equations (5) and (7), we obtain: ${ }^{6}$

$$
\begin{gathered}
\beta_{\tau}=\left(\frac{\tau}{w^{*}} \frac{\partial \Omega}{\partial \tau}\right)-\tau \frac{\partial \Omega}{\partial R} \\
\beta_{\rho}=\rho \frac{\partial \Omega}{\partial R} \\
\frac{\Delta w}{w^{*}}=\beta_{\tau} \frac{\Delta \tau}{\tau}+\beta_{\rho} \frac{\Delta \rho}{\rho}
\end{gathered}
$$

As shown in Appendix A.3), the second-order condition together with the assumption that the objective $U$ is increasing in $c$ ensures that $\beta_{\tau}$ is positive. Moreover, in the labor supply framework, assuming in addition the normality of leisure implies that $\beta_{\rho}$ is negative. Finally, the restriction on $W$ given by Equation (8) implies that:

$$
\beta_{\tau}=\beta_{\tau}^{P}=\beta_{\tau}^{I}>0 \quad \text { and } \quad \beta_{\rho}=\beta_{\rho}^{P}=\beta_{\rho}^{I}
$$

Prediction (9) is obtained in the very large class of benchmark models. Therefore, if estimating Equation (6) leads to reject (9), it means that the abovementioned models are rejected by the data. One should then look for alternative frameworks that can account for such departures. We have a priori three alternatives in mind that we now describe.

First, income tax reforms and payroll tax reforms may be considered differently. For instance, one can argue that, as payroll taxes are paid on a monthly basis while income tax are paid on an annual

\footnotetext{
${ }^{6}$ The case with only one relevant tax schedule can be figured out by considering that $\tau^{\mathrm{P}}=1$ and $R^{\mathrm{P}}=0$, implying that $\tau=\tau^{\mathrm{P}}, R=R^{\mathrm{P}}$ and $\rho=\rho^{\mathrm{P}}$. Equations (5), (7) and (6) then directly give (5'), (7') and (6'). See Appendix A.2)
} 
basis with one year lag, wages react more rapidly to changes in payroll tax and more slowly to changes in income tax. In this case, $\beta_{\tau}^{I}$ and $\beta_{\rho}^{I}$ are expected to have the same sign but a lower magnitude than $\beta_{\tau}^{P}$ and $\beta_{\rho}^{P}$ respectively. Conversely, one may argue that individuals are much more aware of the income tax schedule than of the payroll tax schedule. This would imply that $\beta_{\tau}^{I}$ and $\beta_{\rho}^{I}$ have the same sign but a larger magnitude than respectively $\beta_{\tau}^{P}$ and $\beta_{\rho}^{P}$.

Second, payroll taxes finance various social programs. For some of these programs, both the eligibility and the benefit level are related to the payroll taxes paid. The most illustrative example is the pension system, where the benefit level received upon retirement depends explicitly on both the level and duration of contributions. Unemployment insurance and health insurance also belong to this type of programs. In case of job loss, the maximum duration of UI benefits depend on the duration of contributions. In case of sick leave, health insurance gives benefits that again depend on the level of past contributions. When payroll taxes per se generate benefits with some probability, the objective to maximize must be modified by adding a function of the level of payroll taxes into consumption. Therefore, the gross wage solves:

$$
w=W\left(\tau^{P}, \tau^{I}, R^{I}, R^{P}\right) \equiv \underset{w}{\arg \max } U\left(\tau w+R+k\left(\left(1-\tau^{p}\right) w-R^{P}\right), w\right)
$$

In this specification, the parameter $k$ captures how the overall level of consumption depends on the level of payroll taxes through the payments of various social benefits. Different arguments suggest that $k$ is small. First, benefits depend only partially on the individuals' contribution. Second, as the level of benefits paid depends on the whole labor market history (in particular for pensions), current contributions determine only partially this level. Third, these benefits will be given only in the future, and with some probability, which generates discounting. We hence assume that $k<\tau^{I}$ and $k<\rho^{I}$. As the objective to be maximized does no longer verify restriction (8), prediction (9) is not verified as well. Actually, when the benefit level depends on the payroll taxes paid, the elasticity with respect to the marginal (average) payroll net-of-tax rate is lower (lower in absolute term). We show in the Appendix A.4) that (9') is verified instead of (9):

$$
0<\beta_{\tau}^{P}<\beta_{\tau}^{I} \quad \text { and } \quad\left|\beta_{\rho}^{P}\right|<\left|\beta_{\rho}^{I}\right|
$$

Third, consider a labor supply model where individuals have preferences $u(c, L)$ over consumption $c$ and labor supply $L$. Under perfect competition, an individual's hourly gross wage equals her marginal product of hours of work. Now, assume instead that the hourly posted wage denoted $s$ is rigid. Then, when a worker supplies $L$ units of labor, she receives the posted wage $z=s L$. 
Given the budget constraint (2), she thus chooses her labor supply to maximize $U(c, z)=u(c, z / s)$. Therefore, the posted wage chosen does not depend on the payroll tax parameters, implying that:

$$
\frac{\Delta z}{z^{*}}=\beta_{\tau}^{I} \frac{\Delta \tau^{I}}{\tau^{I}}+\beta_{\rho}^{I} \frac{\Delta \rho^{I}}{\rho^{I}}
$$

Given that $z=\rho w$, one has that $\Delta w / w=\Delta z / z-\Delta \rho^{\mathrm{P}} / \rho^{\mathrm{P}}$. Therefore, we get, instead of (9):

$$
\beta_{\tau}^{P}=0 \quad \beta_{\tau}^{I}>0 \quad \text { and } \quad \beta_{\rho}^{P}=-1
$$

\section{Empirical strategy}

Our objective is to evaluate separately the responses of annual gross wages to reforms to the payroll and of the income tax schedules. This has so far not been done in the literature, one reason being that the identification of the parameters requires observing reforms to both tax schedules on the same individuals and the same period. We thus estimate the following empirical counterpart of Equation (6), which writes for an individual $i$ employed in years $t-1$ and $t$ :

$$
\Delta \log w_{i, t}=\alpha+\beta_{\tau}^{P} \Delta \log \tau_{i, t}^{P}+\beta_{\tau}^{I} \Delta \log \tau_{i, t}^{I}+\beta_{\rho}^{P} \Delta \log \rho_{i, t}^{P}+\beta_{\rho}^{I} \Delta \log \rho_{i, t}^{I}+\gamma \cdot X_{i, t-1}+u_{i, t}
$$

where $\Delta$ is the time-difference operator between dates $t$ and $t-1, X_{\mathrm{i}, \mathrm{t}-1}$ is a vector of observed individual characteristics at $t-1$, and $u_{\mathrm{i}, t}$ is an error term that captures unobserved heterogeneity. In specifying the empirical setup, we are aware that heterogeneous individuals may respond to tax changes differently. Hence, we only provide evidence on the average of these behavioral elasticities, i.e. on the Local Average Treatment Effect (LATE).

As mentioned above, a large class of models of the labor market predicts that gross wages respond identically to changes in the payroll and income tax schedules (see Equation (9)). In such a case, the true model is given by Equation (6') with the following empirical counterpart:

$$
\Delta \log w_{i, t}=\alpha+\beta_{\tau} \Delta \log \tau_{i, t}+\beta_{\rho} \Delta \log \rho_{i, t}+\gamma \cdot X_{i, t-1}+u_{i, t}
$$

The latter specification differs from the existing literature on two points. First, we investigate the effect of taxes on gross wages while most previous studies are interested in the responses of broad or of taxable income. Second, we consider changes in the marginal and average net-of-tax rates of both income and payroll tax schedules, while the literature focuses on tax rates from either the income 
(e.g. Feldstein, 1995, Auten and Carrol, 1999, Gruber and Saez, 2002) or the payroll tax schedules (e.g. Saez, Matsaganis and Tsakloglou, 2010).

Various methodological issues complicate estimation, some ones being well known and some others less. The first issue concerns the potential simultaneity bias. Because of the nonlinearity of, respectively, the payroll and the income tax schedules, the marginal net-of-tax rates $\tau_{i, t}^{P}$ and $\tau_{i, t}^{I}$ are functions of the gross wage level. Similarly, the average net-of-tax rates $\rho_{i, t}^{P}$ and $\rho_{i, t}^{I}$ depend on the gross wage, the reason being that the marginal and the average rates differ. In order to isolate the impact of taxes on gross wages, we need instruments for $\Delta \log \tau_{i, t}^{j}$ and $\Delta \log \rho_{i, t}^{j}$, with $j=P$,I. In the literature, the standard procedure, proposed by Auten and Caroll (1999), is to instrument the change in tax rates for an individual $i$ between years $t-1$ and $t$, by the simulated change in the tax rate would her year $t$ wage be equal to her year $t-1$ inflation-adjusted wage. By construction, the instrument captures changes in the tax rate absent any behavioral response. While Auten and Caroll apply this procedure only to the marginal income net-of-tax rate, Gruber and Saez (2002) extend this procedure to their income effect term. We propose a further extension by applying this method separately to the marginal and the average net-of-tax rates associated with the two tax schedules. Let $\bar{w}_{i, t-1}=w_{i, t-1} \times \pi_{t-1}$ denote the base-year inflation-adjusted gross wage, where $\pi_{\mathrm{t}-1}$ is the average growth rate of gross wages between years $t-1$ and $t$. We note with an upper bar the marginal and average net-of-tax rates simulated by applying the year $t$ tax schedule to ${ }^{2}$. We then define for $j=P, I$ :

$$
\bar{\tau}_{i, t}^{j}=1-\frac{\partial T^{j}\left(\bar{w}_{i, t-1} ; t\right)}{\partial w} \quad \text { and } \quad \bar{\rho}_{i, t}^{j}=1-\frac{T^{j}\left(\bar{w}_{i, t-1} ; t\right)}{w}
$$

For $j=P, I$ and $\varphi=\tau, \rho$, we define the "type-I" instrument as $\Delta \log \bar{\varphi}_{i, t}^{j}=\log \bar{\varphi}_{i, t}^{j}-\varphi_{i, t-1}^{j}$.

A second issue is the existence of non-tax related changes in gross wages. Technical progress does not lead to uniform wage increases across the population. Empirical evidence suggests that technical progress benefited more to high-skilled workers than to the others. International trade may also have heterogeneous effects, leading presumably to a widening of the wage distribution. Changes in gross wages not due to tax reforms are likely to be different across firm size and industry, age category, level of education, etc. The risk when evaluating a tax reform that reduces the marginal tax rate for top income earners such as TRA86 in the U.S., is to attribute changes in wages to the reform rather than to such "non-tax" causes, thereby generating an upwards bias of the estimate (Gruber and Saez (2002)). To address this issue, we need good controls in the vector $X_{\mathrm{i},-1-1}$. As will be shown later, our data set presents the advantage of including detailed information on individual characteristics (in particular age, sex, education, occupation, labor market history) and firm characteristics (industry, 
size, position with respect to the 35-hour arrangement), thus allowing us to better control for non-tax related changes.

Reversion-to-the-mean constitutes another source of non-tax factors. When an individual gets an unusually low (respectively high) labor income in period $t-1$, she will very likely get a higher (lower) labor income in the following period. This is typically what happens when an individual enters unemployment (respectively involuntary part-time work) during year $t-1$. Her labor income is then unusually low and increases substantially in year $t$ if she finds a permanent (full-time) job. In order to control for reversion-to-the-mean, the standard procedure in the literature is to include a flexible function of base income $f\left(\log w_{\mathrm{i}, t-1}\right)$ in the vector of controls $X_{\mathrm{i}, \mathrm{t}-1}$. Auten and Caroll (1999) use a linear function while Gruber and Saez (2002) use a very flexible 10-piece spline. A flexible specification allows one to better control for reversion-to-the-mean but may destroy identification (Saez, Slemrod and Giertz (2010)). Given this tradeoff, we choose to include a 5-order polynomial of the log of base gross wages in the list of controls.

However, including $f\left(\log w_{\mathrm{i}, \mathrm{t}-1}\right)$ and detailed information on individual and firm characteristics in $X_{\mathrm{i},-\mathrm{-}-1}$ may be insufficient to control for mean reversion or trends in the gross wage distribution ${ }^{7}$ if the residuals of Equation (10) are serially correlated. Formally, the condition $\mathbf{E}\left(u_{i, t} \mid \log w_{i, t-1}\right)$ holds if and only if $u_{\mathrm{i}, \mathrm{t}}$ is a white noise process. ${ }^{8}$ If this condition is not verified (Holmlund and Söderström, (2008), Blomquist and Selin (2010)), $\log w_{\mathrm{i}, \mathrm{t}-1}$ (and the subsequent terms of the polynomial) must be instrumented. As our data set provides information on gross wages in year $t-2$, a natural instrument for $w_{\mathrm{i},-1-1}$ is $\bar{w}_{i, t-2}=w_{i, t-2} \times \pi_{t-2}$, where $\pi_{t-2}$ denotes the growth rate of average gross wages between years $t-2$ and $t-1$. This instrument is valid provided that the error term $u_{i, t}$ follows a MA(1) process. Assuming that $\log \bar{w}_{i, t-2}$ is a valid instrument for $\log w_{\mathrm{i}, \mathrm{t}-1}$, we are able to test for the exogeneity of $\log w_{\mathrm{i}, t-1}$. Moreover, $\mathbf{E}\left(u_{i, t} \mid \log w_{i, t-1}\right) \neq 0$ may also (but not necessarily ${ }^{9}$ ) imply that $\Delta \log \bar{\varphi}_{i, t}^{j}$ is not a valid instrument for $j=P, I$ and $\varphi=\tau, \rho$. This leads us to propose a second group of instruments based on year t-2 inflation adjusted gross wages $\overline{\bar{w}}_{i, t-2}=w_{i, t-2} \times \pi_{t-1} \times \pi_{t-2}$ for year $t$, and on $\bar{w}_{i, t-2}=w_{i, t-2} \times \pi_{t-2}$ for year $t-1$. We then define, for $j=P, I$ :

\footnotetext{
${ }^{7}$ In the literature, there is no proof that this procedure is sufficient.

${ }^{8}$ Equivalently, the process of the residuals of the wage equation in levels is a random walk.

${ }^{9}$ The endogeneity of $w_{\mathrm{i}, t-1}$ does not necessarily imply the endogeneity of the instruments, because $\bar{\tau}_{i, t}, \bar{\tau}_{i, t}$, $\bar{\rho}_{i, t}^{P}$ and $\bar{\rho}_{i, t}^{I}$ are non-monotonic functions of $w_{\mathrm{i}, \mathrm{t}-1}$ (see Figures $2,4 \mathrm{a}$ and $4 \mathrm{~b}$ ).
} 


$$
\begin{aligned}
& \bar{\tau}_{i, t}^{j}=1-\frac{\partial T^{j}\left(\overline{\bar{W}}_{i, t-2} ; t\right)}{\partial w} \quad \text { and } \quad \bar{\rho}_{i, t}^{j}=1-\frac{T^{j}\left(\overline{\bar{W}}_{i, t-2} ; t\right)}{w} \\
& \bar{\tau}_{i, t-1}^{j}=1-\frac{\partial T^{j}\left(\bar{w}_{i, t-2} ; t-1\right)}{\partial w} \quad \text { and } \quad \bar{\rho}_{i, t-1}^{j}=1-\frac{T^{j}\left(\bar{w}_{i, t-2} ; t-1\right)}{w}
\end{aligned}
$$

Using the above definitions, type-II instrument for $\Delta \log \varphi_{i, t}^{j}$ is given by $\Delta \log \overline{\bar{\varphi}}_{i, t}^{j}=\log \overline{\bar{\varphi}}_{i, t}^{j}-\log \bar{\varphi}_{i, t-1}^{j}$, with $j=P, I$ and $\varphi=\tau, \rho$. Having two instruments for $\Delta \log \varphi_{i, t}^{j}$ allows us to test their validity. ${ }^{10}$

\section{The data}

The existing literature most often uses administrative income (e.g. Feldstein, 1995, Auten and Caroll, 1999, Gruber and Saez, 2002) or payroll tax records (e.g. Saez et alii, 2010). Although administrative tax records have the advantage of providing exhaustive and longitudinal data, they contain limited information on individual characteristics and no information on labor market history and firms characteristics. Since the main goal for collecting these data is policy-oriented, only the variables necessary to compute taxes are provided. In contrast to the existing literature, we use a research-oriented data set, the Enquête Revenus Fiscaux (hereafter ERF), resulting from the match of the French Labor Force Survey (hereafter LFS) to administrative income tax records. Specifically, the individuals interviewed at the $4^{\text {th }}$ quarter of year $t$ in the LFS are matched with their $t+1$ administrative income tax records to generate the year $t$ ERF dataset. The LFS is a rotating 18-month panel that starts a new 18-month wave every quarter. As individuals are interviewed during six consecutive quarters, they can at best appear during two consecutive years in the ERF dataset. We use the 2003-2006 waves of the ERF and restrict the sample to individuals that appear during two consecutive years. We choose this period because reforms to both the payroll and the income tax schedules occurred during this period for similar individuals. The individuals we observe appear either in 2003 and 2004, in 2004 and 2005, or in 2005 and 2006. As the French LFS contains detailed information on personal characteristics (in particular education), labor market history and the characteristics of the job (in particular usual weekly hours of work, industry), we are able to control in a rich way for mean reversion and for other trends in the gross wage distribution.

We now turn to the wage variable provided by our dataset. The administrative income tax records contain information on the annual posted wage earned by each member of the household (i.e. $z$ defined as the gross wage minus payroll taxes). The variable is reported by the employer and

\footnotetext{
${ }^{10}$ Holmlund and Söderström (2008) use the same instrument as our type-II ones. Blomquist and Selin (2010) propose another strategy. They regress both $w_{\mathrm{i}, 1991}$ and $w_{\mathrm{i}, 1981}$ on $w_{\mathrm{i}, 1986}$ and on a set of controls and use the predicted values to build their instruments. In any case, instruments are valid only under some assumption on the serial correlation of the residuals.
} 
controlled by the fiscal administration, and as such is reliable. However, our aim in this work is to evaluate the respective effects of payroll and income taxes on gross wages. While the ERF does not directly provide gross wages, it contains all the information necessary to reconstruct this variable by applying the legislation on employer and employee payroll taxes. Payroll taxes are paid each month. They are calculated as a function of the monthly and hourly posted wages, the firm size, the type of work, ${ }^{11}$ and whether or not the firm has moved to the 35-hour workweek. As the LFS contains all these variables (with the exception of the 35-hour workweek, which is inferred ${ }^{12}$ ), we can reconstruct payroll taxes, and thereby gross wages. The monthly posted wage is obtained by matching the annual amount drawn from tax records to the labor market history described by the LFS. ${ }^{13}$

We build our own simulator for the payroll tax system. For the income tax schedule, we use a tax simulator adapted from the INES (INsee Etudes Sociales) micro-simulation model provided by INSEE and DREES). Using these simulators, we compute the average payroll and income taxes, and simulate the marginal payroll and income tax rates generated by a $5 \%$ increase in posted wages. Administrative tax records provide also information on posted wages at $t-2$. Hence, we are able to compute our two types of instruments: instrument I based on $w_{\mathrm{i}, \mathrm{t}-1}$ and instrument II based on $w_{\mathrm{i}, \mathrm{t}-2}$.

We restrict the sample to individuals who experienced no change in their marital status between dates $t-1$ and $t$, since those who marry, divorce, or become widowed have to report several fiscal returns. In addition, we exclude public sector workers, as they face up very specific labor market regulations. We also exclude the individuals for whom we cannot determine with a high degree of certainty whether or not they work under the 35-hour arrangement. Finally, we restrict the sample to individuals who report a positive labor income at dates $t-1$ and $t$.

Our final sample comprises 14,311 individuals observed at two consecutive years. In this sample, the distribution of gross $w$ is described by:

\begin{tabular}{|l|c|c|c|c|c|c|c|c|}
\hline & Mean & $\begin{array}{c}\text { Standard } \\
\text { deviation }\end{array}$ & D1 & Q1 & Median & Q3 & D9 & P99 \\
\hline Gross wage $w$ & 35,953 & 31,053 & 14,056 & 21,658 & 30,901 & 43,067 & 60,367 & 124,690 \\
\hline
\end{tabular}

Table 1 : distribution of the gross wage $w$

Figure 1 describes for each year the growth rate of gross wage $\Delta \log w_{\mathrm{i}, \mathrm{t}}$ along the wage distribution. To make theses curves comparable across time, we represent these rates as a function of the ratio of the individual gross wage to the labor income of a full-time minimum wage worker. Given

\footnotetext{
${ }^{11}$ Engineers, managers and professionals face a specific payroll tax code.

${ }^{12}$ Using the legal and usual weekly hours of work, and the existence of additional holidays (RTT days), we are able to infer with a high degree of certainty whether the individual is working in a "35-hour firm" or in a "39hours firm" for $95.5 \%$ of the sample.

${ }^{13}$ Each quarter, the individuals interviewed in the LFS report their posted monthly wage. As this information is self-declared, it is less reliable than the annual posted wages provided by the fiscal administration, and we do not use it.
} 
the variability of growth rates of gross wages among individuals with the same earnings level, we compute the means within each percentile of posted wage (which also corresponds to each percentile of the ratio of posted wage over labor income of a full-time minimum wage worker) for each year. Figure 1 stresses the reversion to the mean phenomenon at the bottom end of the wage distribution. The most plausible explanation for this fact is exits from unemployment.

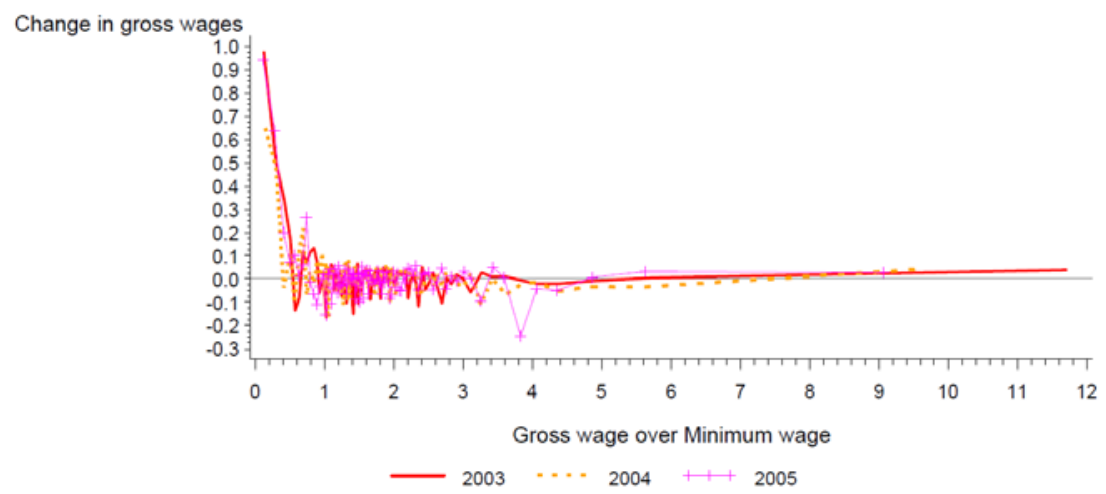

Figure 1: means of the growth rate of gross wage for each centile of the wage distribution

Table 1 contains some further descriptive statistics.

\begin{tabular}{|c|c|c|c|}
\hline Age between 20 and 29 y.o. & $14.31 \%$ & Industry is manufacturing & $26.17 \%$ \\
\hline Age between 30 and 39 y.o. & $29.17 \%$ & Industry is agriculture & $1.68 \%$ \\
\hline Age between 40 and 49 y.o. & $32.13 \%$ & Industry is construction & $7.24 \%$ \\
\hline Age between 50 and 59 y.o. & $23.39 \%$ & Industry is energy & $1.49 \%$ \\
\hline Age higher or equal than 60 y.o. & $1 \%$ & Industry in education or social services & $9.74 \%$ \\
\hline Women & $42.39 \%$ & Industry is retail and repair & $17.06 \%$ \\
\hline Women and one more kid since $t-1$ & $2.25 \%$ & Self-employed & $1.01 \%$ \\
\hline One more kid since $t-1$ & $5.74 \%$ & Engineers, managers and professionals & $14.61 \%$ \\
\hline Women and a child exits since $t-1$ & $2.46 \%$ & Less than 10 employees in the firm & $14.83 \%$ \\
\hline A child exits the household since $t-1$ & $6 \%$ & Between 10 and 19 employees & $7.22 \%$ \\
\hline Women and a child under 3 y.o. & $2.02 \%$ & Employer is a "35 hours" firm & $73.76 \%$ \\
\hline Women and a child under 6 y.o. & $4.81 \%$ & Job tenure is less than 1 year & $6.65 \%$ \\
\hline Women and a child under 18 y.o & $15.98 \%$ & Job tenure is between 1 and 5 years & $25.35 \%$ \\
\hline Single individuals in the household & $10.90 \%$ & Job tenure is between 5 and 10 years & $17.78 \%$ \\
\hline Single parents & $6.43 \%$ & Job tenure is more than 10 years & $47.25 \%$ \\
\hline Couples with kids & $21.01 \%$ & Education level is graduate & $11.01 \%$ \\
\hline Complex households & $2.91 \%$ & Education level is college & $17.18 \%$ \\
\hline & Education level is secondary level & $16.16 \%$ \\
\hline & & Secondary education not ended or vocational & $38.15 \%$ \\
\hline & & Junior high school. & $7.59 \%$ \\
\hline
\end{tabular}

Table 2: Descriptive statistics

\section{Institutional backgrounds}

We now describe the reforms to the payroll and income tax schedules that occurred in France during the 2003-2006 period. 


\section{V.1 Income tax reforms}

By "income tax" we intend the income tax per se and a tax credit for low-paid earners (Prime pour l'emploi, hereafter PPE). Income tax per se in France is calculated at the household level. ${ }^{14}$ It is a function of the total income earned by the household divided by the number of "parts" (based on the composition of the household). The amount of tax paid then equals the income tax that would be paid by a single individual with this ratio times the number of parts. This implies that both the marginal and average net-of-tax tax rates of a given individual changes with the spouse's income, at the birth of a child, or when a child becomes adult and exits the household. However, these events are likely to affect also the labor supply decisions, the only exception being the exit of a child which generates an instantaneous change in the tax schedule, while the change in the labor supply, if any, is likely to be smoothed over time. Therefore, income tax reforms provide more convincing sources of identification than these family events. Over the 2003 - 2006 period covered by our data set, there are several changes in the income tax code per se. In 2004 and 2005, tax brackets are indexed for consumer price inflation. This generates a form of bracket 'creeps' (Saez (2003)), as labor earnings have increased more rapidly than inflation over this period. A more substantial reform in 2006 reduces the number of brackets from seven to five and modifies the rates.

However, the reform that generates the larger changes in tax rules over 2003-2006 is the extension of the Prime pour l'emploi, a tax credit created in 2001 and conditional on working. Both eligibility for the tax credit and the amount of subsidy paid depend essentially on the individual fulltime equivalent annual wage, but the total income earned by the household and its composition also intervene. More precisely, eligibility requires that the individual full-time equivalent annual wage is above 0.3 and lower than 1.4 times the minimum wage (2.1 for certain household compositions). Considering the wage distribution in France, ${ }^{15}$ this implies that one-third of the employed are eligible for the tax credit. ${ }^{16}$ We describe now the scheme for a single individual without children (Figure 1). Above 0.3 times the annual minimum wage, there is first a "phase-in" income range where the credit increases proportionally to the wage. The benefit is maximal at the minimum wage level. Phasing-out then begins and ends at 1.4 times the minimum wage. The phase-in income range induces a reduction in both marginal and average tax rates. The phase-out income range generates a rise in the marginal tax rate, since a higher wage reduces the tax credit, and a decrease in the average tax rate. While the PPE scheme remains essentially unchanged in 2004 with respect to 2003, major changes occur both in

\footnotetext{
${ }^{14}$ More precisely, the income tax unit is the «foyer fiscal» which may differ from the household unit in some cases.

${ }^{15}$ In France in 2006, 22\% of the employed earn a wage between 0.3 and 1.4 times the minimum wage, and $50 \%$ get a wage between 0.3 and 2.1 times the minimum wage.

${ }^{16}$ Compared to the EITC or the WFTC, the French tax credit thus differs on two points: a much larger share of the population is eligible; the presence of children has a very limited effect on the amount of benefit.
} 
2005 and 2006, as described in Figure 2. As a result, the maximum level of the subsidy increases from $4.6 \%$ of the annual minimum wage (i.e. $517 €$ per year) in 2003 to $7.7 \%$ in 2006 (i.e. $948 €$ per year).

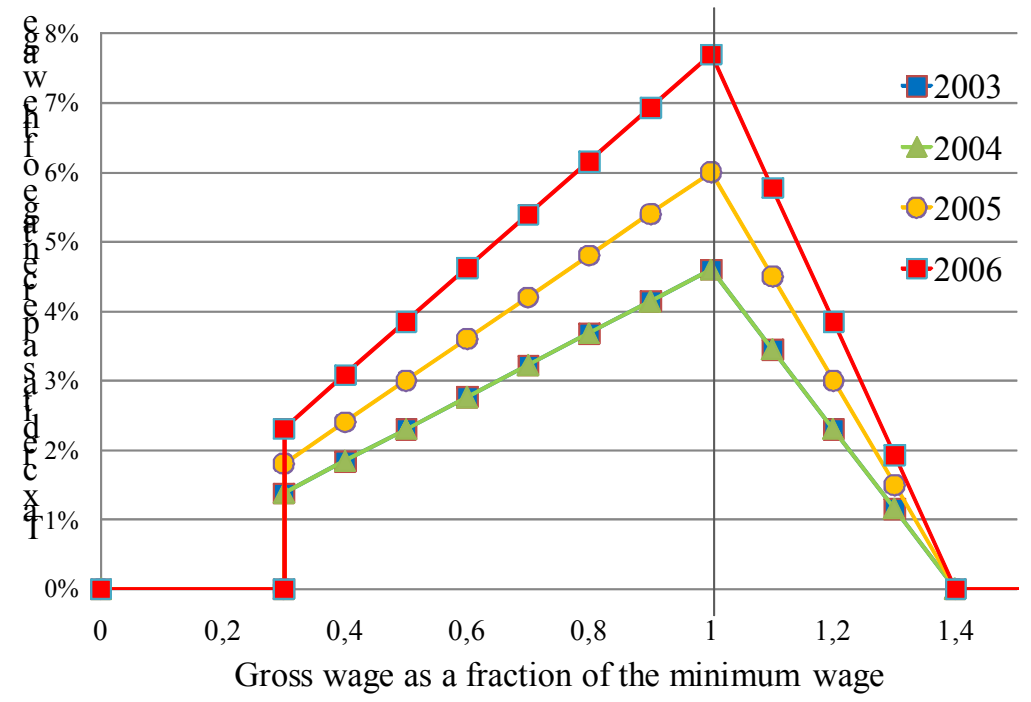

Figure 2 - Reforms to the French income tax credit, 2003-2006

Note: the amount of PPE is expressed as a percentage of yearly labor earnings. The figure describes the scheme for a single worker without children. For couples or singles with children, the "phasing-out" of the PPE scheme can go up to 2.1 times the minimum wage.

Figure $3 \mathrm{a}$ (respectively $3 \mathrm{~b}$ ) depicts the evolution of the marginal $1-\tau^{I}$ (respectively average 1$\rho^{I}$ ) income tax rate simulated on our sample through the years 2003-2006. The first point to note is that the rates are very noisy, especially for part time workers below the full-time minimum wage. Beside, for each year, we observe a sharp increase of marginal tax rates in the phase out part of the wage distribution between 1 and 1.4 times the minimum wage. As expected, the extension of the PPE generates a large increase in the marginal income tax rate in this range. It also reduces the average income tax rate, especially at the minimum wage level where the PPE is maximal. The tax reforms generated by the income tax per se are conversely much less apparent in the data, except for the reduction in the average tax rate between 2005 and 2006 for gross wages above two times the minimum wage.

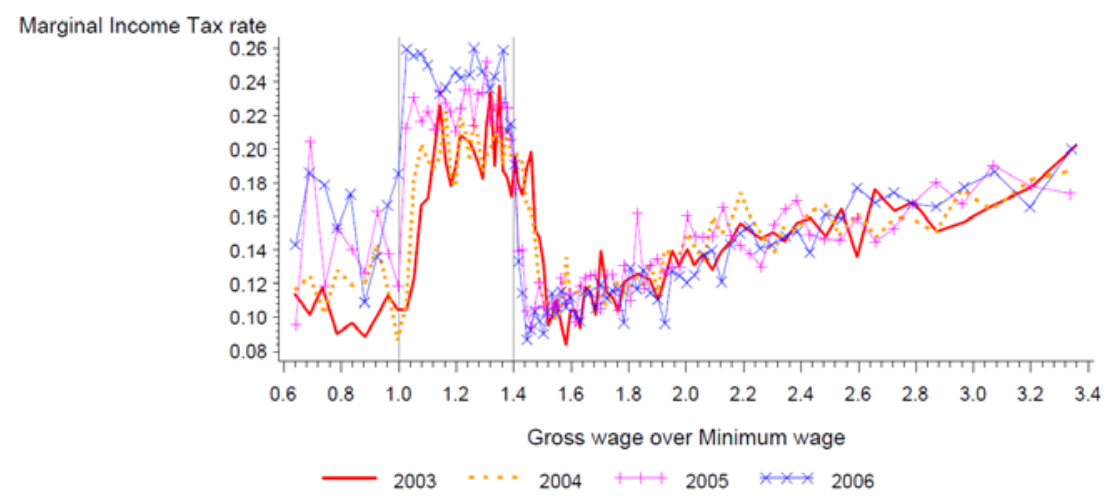

Figure 3a: Marginal Income Tax rates 


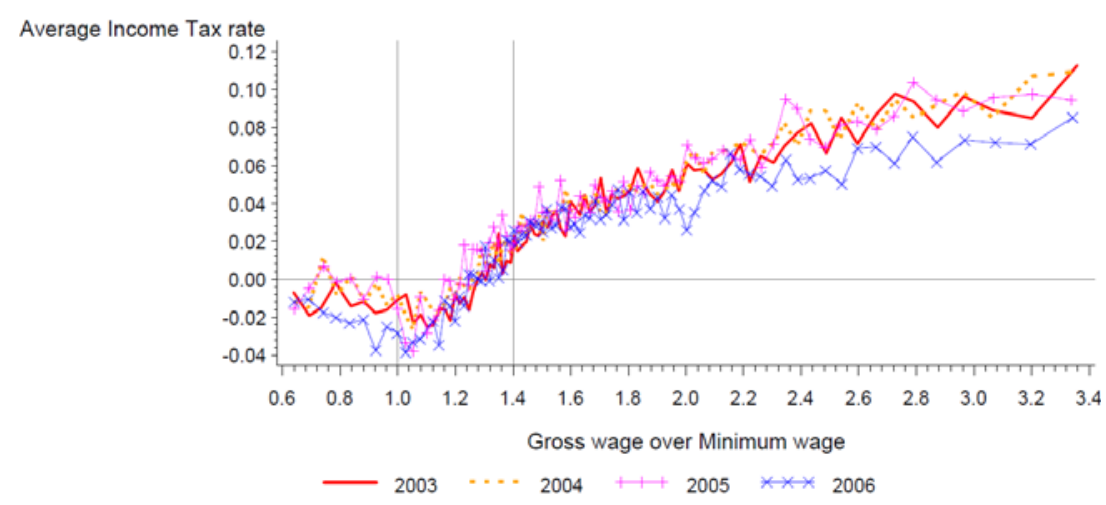

Figure 3b: Average Income Tax rates

\section{V.2 Payroll tax reforms}

In almost all countries, payroll taxes are flat, apply only to earnings below a given cap, collect about the same percentage of total revenue than income taxes, and are essentially invariant over time. As they are flat and time-invariant, their effect is difficult to identify, which explains that there is few empirical works on how payroll taxes affect labor supply and labor demand. By contrast, in France, payroll taxes collect a higher share of total revenue than income taxes. The rate of payroll taxes paid is a function of wages since the introduction in 1993 of a reduction in employer payroll taxes for lowwage earners.

Since June 1998, the situation was complicated further by the existence of two reduction schedules, depending on whether or not the employee is working under the 35 -hour arrangement. At this date, the Aubry law, implemented by the left-wing government Jospin initiated the move to a 35hour week, a process that became mandatory for all private companies with more than 20 employees in January 2000. The firms moving from a 39-hour to a 35-hour workweek (hereafter the 35-hour firms) were given an additional reduction in employers-paid payroll taxes compared to the firms remained at 39 hours (hereafter the 39-hour firms). As all firms were intended to move to the 35 hours, the existence of two types of tax subsidies was not a long-term problem. However, the process of reduction in the workweek was stopped in 2002 when the right-wing government Raffarin came into power. At this date, a non-negligible proportion of firms had not moved to the 35-hour workweek and had no intention to move later. As a result, a law in January 2003 was planning the creation of a unique tax subsidy schedule (called Fillon reduction), that applied whether or not the firm had moved to the 35-hour workweek. This latter schedule is still applied today. The convergence process lasted three years.

Figure 4 presents the changes in the tax subsidy from 2003 to 2006 for the two types of firms. At the beginning, in January 2003, the two subsidy schedules differ substantially. For a 39-hour firm (solid curves), the reduction in employer payroll taxes reaches a maximum of 18.2 percentage points at 
1 times the hourly minimum wage, then decreases up to 1.3 times the minimum wage. For a 35 -hour firm (dashed curve), the reduction is maximal at 1.076 times the hourly minimum wage and equal to 26 percentage points, and decreases up to an amount around 1.94 times the minimum wage. ${ }^{17}$ For the 39-hour firms, the percentage points of reduction at the minimum wage increases from 18.2 in 2003 to 26 in 2006. Moreover, the phase-out income range widens from an initial 1 to 1.3 times the minimum wage to 1 to 1.6 times the minimum wage. For the 35 -hour firms, the maximum percentage points of reduction remains unchanged, but the phasing-out part of the program goes from 1.076 to 1.94 times the minimum wage to 1 to 1.6 times the minimum wage. In average over the period 2003-2006, the tax subsidy decreases for the 35 -hour firms while increasing for the 39-hour ones.

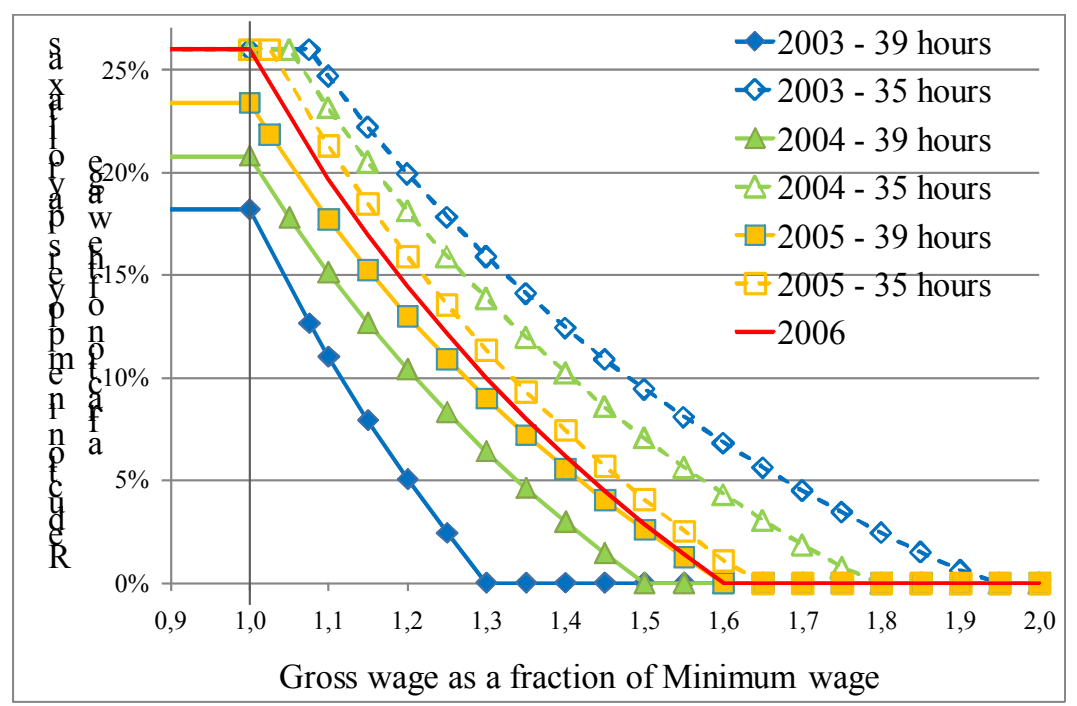

Figure 4 - Changes in the reduction in employer payroll taxes for low paid earners, 2003 to 2006

When simulating the payroll taxes on our sample of individuals, we observe that the marginal rates are much higher in the phase-out part of the wage distribution than elsewhere. For those employed in the 35 hours firms, we observe that the range of wages where marginal tax rates are very high shrinks over time (See Figure 5a). Average tax rates are similar for all years at the minimum wage level and above 2 times the minimum wage. However, as time goes by, the higher level of average payroll tax rates is reached for smaller wage level, as expected from the description of the reform (see Figure 5b).

\footnotetext{
${ }^{17}$ In order to prevent the reduction in the work week to lower the monthly wage, the (hourly) minimum wage regulation (SMIC for Salaire Minimum Interprofessionnel de Croissance) was supplemented by a system of monthly minimum wage regulation called GMR (Guarantie Mensuelle de Rémunerations) which depends also on the date at which firms adopted the 35-hour work week. In 2003 for a firm having moved to the 35-hour in 2000 , the GMR2 is equal to 1.076 times the minimum wage. The reduction is maximal at 1 times the GMR and decreases up to 1.8 times the GMR. The GMR has decreased with respect to the minimum wage from 2003 to 2006.
} 


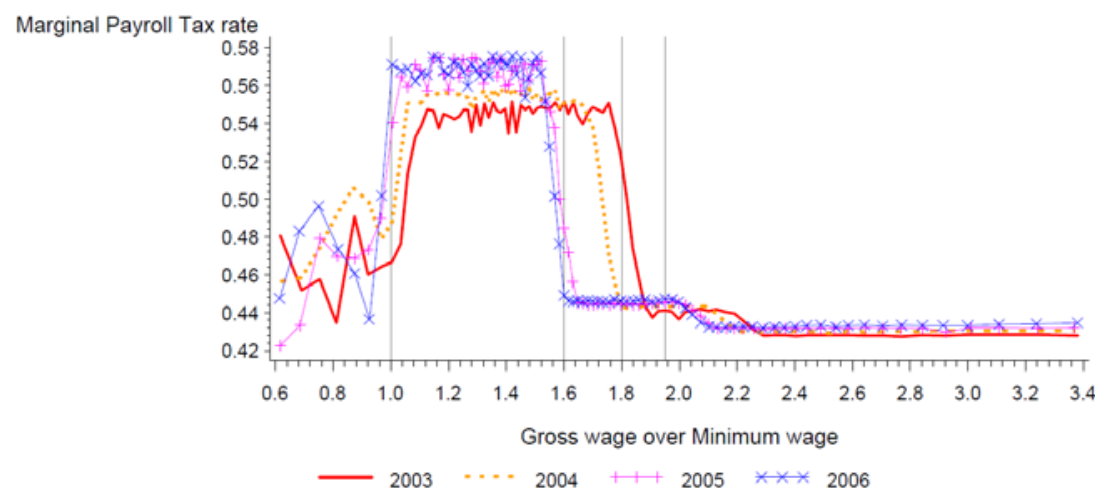

Figure 5a: Marginal payroll tax rate for the 35-hour firms

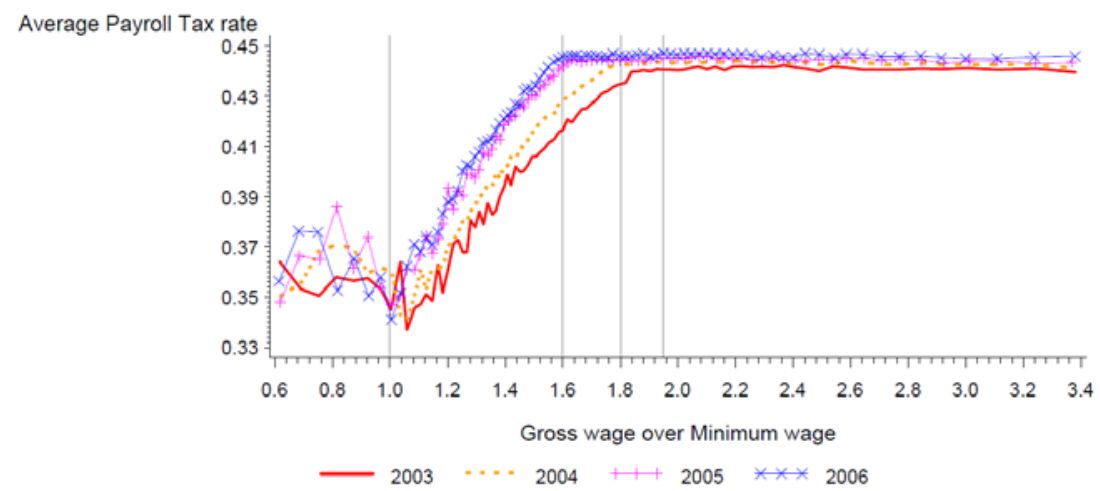

Figure 5b: Average payroll tax rate for the 35 -hour firms

For those employed in 39-hour firms, we observe a rise in marginal payroll tax rates from 2003 to 2006, as the phase-out portion of the wage distribution widens (see Figure 6a). We also observe a decrease in the average payroll tax rate at the minimum wage level (see Figure 6b). This reduction vanishes progressively as one moves rightwards along the wage distribution.

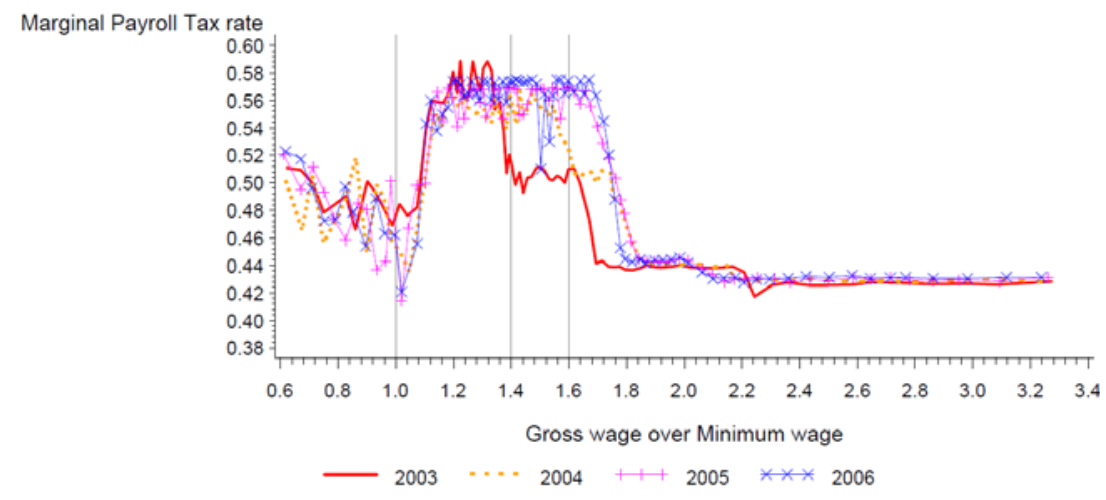

Figure 6a: Changes in the marginal payroll tax rate for the 39-hour firms 


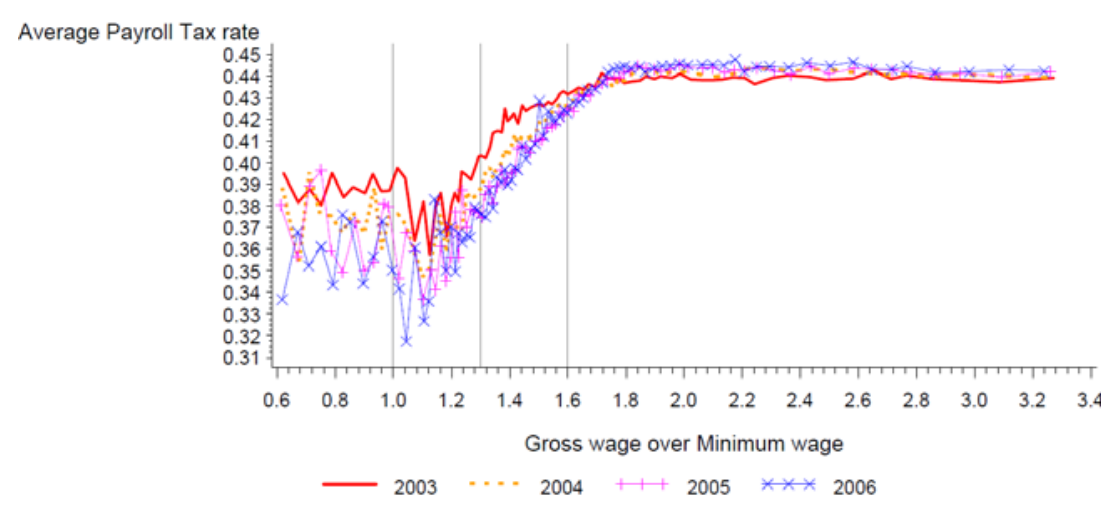

Figure 6b: Changes in the average payroll tax rate for the 39-hour firms

\section{Results}

\section{VI.1 Effects of payroll and income taxes}

We first estimate Equation (10) using the 2SLS approach. The Sargan test leads us to conclude that type-I and type-II instruments are valid. The first-stage regressions are displayed in Table 6 of Appendix B. The F-statistics of the excluded instruments are always high meaning that the instruments are strongly correlated with the instrumented regressors. As type-I instruments are better for marginal net-of-tax rates, and type-II instruments better for average net-of-tax rates, we choose to use both of them.

Table 3 displays our estimates of the gross wages responses for various sets of controls. In Column 1, the only covariates are time dummies and five order polynomial in the log of the base year gross wage. In Column 2, we add socio-demographic covariates drawn from tax records concerning age, gender and the composition of the household. In Column 3, the set of covariates furthermore includes variables drawn from the LFS. They concern educational level, type of occupation, firm size, industry, job tenure and whether the firm has moved to the 35-hours workweek. Moreover, the minimum wage regulation has evolved very differently in the two groups of firms in the period we consider. In 2002, the binding minimum wage regulation (GMR) for 35 hours firms implied a minimum wage $8.2 \%$ higher than for 39 hours firms. As for the payroll tax schedule, the difference between these two regulations vanishes progressively until July $1^{\text {st }} 2005$. To account for this discrepancy, we introduce one dummy indicating whether the firm has moved to the 35-hours workweek per year. The full results are presented in Table 7 in Appendix B.

We first examine the elasticity with respect to the marginal income net-of-tax rate. The elasticity estimate is around 0.3, significant, and varies very slightly with the set of covariates included. Our results are thus consistent with those of Blomquist and Selin (2010) for males in Sweden, who find an elasticity of taxable labor income around 0.25 . Our estimate also belongs to the $[0.12 ; 0.4]$ interval that Saez, Slemrod and Giertz (2010) argue is the most plausible. It is worth noting, 
however, that they consider taxable income, not taxable labor income, and believe the former to be more responsive to taxation. In particular, Saez (2003), comparing the effect of taxes on different definitions of income in the U.S. over the period 1979-1981, finds significant responses of both taxable income and adjusted gross income, while he estimates an elasticity of labor income which is close to zero. Another difference with the existing literature is that we use reforms whose stronger effects occur for individuals below the median of the wage distribution, whereas most of the literature uses reforms occurring in the top of the distribution. High-income individuals are expected to be more sensitive to taxes, in particular because they have more access to avoidance opportunities. The literature usually considers that responses to marginal tax rates are essentially driven by those individuals (e.g. Gruber and Saez (2002)). Our results thus show that significant responses may also arise for low or median-income individuals.

\begin{tabular}{|c|c|c|c|}
\hline & $(1)$ & $(2)$ & $(3)$ \\
\hline \hline$\beta_{\tau}^{I}$ & $0.313^{* *}$ & $0.352^{* *}$ & $0.338^{* *}$ \\
& $(0.149)$ & $(0.160)$ & $(0.169)$ \\
\hline$\beta_{\tau}^{P}$ & -0.037 & 0.038 & 0.053 \\
& $(0.147)$ & $(0.157)$ & $(0.163)$ \\
\hline$\beta_{\rho}^{I}$ & $-0.962^{*}$ & -0.698 & -0.618 \\
& $(0.510)$ & $(0.628)$ & $(0.743)$ \\
\hline$\beta_{\rho}^{P}$ & $-1.527^{* * *}$ & $-1.595^{* * *}$ & $-2.025^{* *}$ \\
& $(0.460)$ & $(0.483)$ & $(1.007)$ \\
\hline \hline Tax records variables & No & Yes & Yes \\
\hline LFS variables & No & No & Yes \\
\hline P value of Sargan Test & $12.78 \%$ & $12.78 \%$ & $22.07 \%$ \\
\hline $\mathrm{N}^{\circ}$ of Observations & 14311 & 14311 & 14311 \\
\hline
\end{tabular}

Table 3 - Estimates of the elasticities with respect to the net-of-tax rates

Source: ERF survey, Insee, 2003-2006. Notes: standard errors in parentheses. * denotes significance at $10 \%$, ** significance at $5 \%$ and $* * *$ significance at $1 \%$. Estimation by 2 SLS using instruments I and II. All regressions also include time dummies, the position with respect to the 35 hours arrangement and a 5 -th order polynomial of base year gross wages.

Conversely, our estimate for the effect of marginal payroll net-of-tax rates on gross wages $\beta_{\tau}^{P}$ is close to zero and not significant. This finding is obtained whatever the set of controls. This finding is in line with Saez, Matsaganis and Tsakloglu (2010) for Greece and with Aeberhardt and Sraer (2009) for France. However, it differs from Lhommeau and Remy (2009), also for France, who find that the progressivity of payroll taxes has a negative effect on wage growth. Our result that gross wages do not respond to marginal payroll tax rates suggests that, at least in the short run, the efficiency costs of financing social security expenses and redistribution through payroll taxes are lower than through income taxes.

We turn now to income effects. The elasticity with respect to the average income net-of tax rate is negative but not significant (or weakly significant in Column 1), which is consistent with the literature (e.g. Gruber and Saez (2002)). By contrast, we find that the elasticity with respect to the average payroll net-of-tax rate is negative and significant. The parameter varies between -1.5 and -2 , 
and decreases when adding LFS controls. However, we cannot reject that it is equal to -1 , which suggests that wages are negotiated net-of employer payroll taxes. In terms of incidence, this means that employers pay employer-payroll taxes. In other words, a decrease in employer payroll taxes seems almost entirely absorbed by employers and thus actually reduces the labor cost, without any significant effect on posted wages.

Our result that gross wages are insensitive to marginal payroll tax rates, whereas they respond to income tax rates have important implications. Section II shows that a large class of theoretical models of the labor market predicts identical elasticities, as expressed by (9). This class includes the textbook labor supply model where the hourly gross wage equals the marginal productivity of labor. The evidence for France is that Equation (9) is rejected. This therefore suggests that the textbook "competitive - labor supply" model that underlies most of public finance analysis (e.g. Mirrlees (1971)) may be inadequate.

Moreover, our estimates also lead us to reject prediction (9') since gross wages respond more to marginal income than to marginal payroll net-of-tax rates, but less to average income than to average payroll net-of-tax rates. As argued in Section II, our results are not supportive of the idea that people understand differently the consequences of income taxes and payroll taxes. Our findings also reject models where payroll taxes generate benefits that are internalized in the formation of the gross wages.

Conversely, our findings are consistent with (9") which was obtained under the assumption that individuals choose their labor supply under the assumption that the hourly posted wages are rigid. This in particular implies that the hourly gross wage differs from the marginal productivity of labor, a key departure from the assumption of a perfectly competitive labor market. A plausible explanation is that wage negotiations take place over hourly posted wages and has not yet react in year $t$ to reforms of the payroll tax schedule that took place between year $t-1$ and year $t$.

\section{VI.2 Heterogeneous effects}

In this Section, we are interested in the effects of taxes on gross wages across subgroups. This will also help us to understand the economic behaviors behind our results. First, as mentioned above in section $\mathrm{V}$, those working 35 hours and those employed in 39-hour firms have been subjected to very different shocks. In order to verify the robustness of our main result that wages respond very differently to income and payroll taxes, we run separate analyses for the two types of employees. The results are reported in Table 4 with the larger set of covariates. The first Column reports results for the overall sample, and is thus identical to the third column of Table 3. Columns (2) and (3) report the estimates separately for those employed in 39-hour firms and those working 35 hours. The main results found for the whole population remain qualitatively unchanged, implying that Equations (9) and (9') are rejected while Equation (9'') is consistent with the data. 


\begin{tabular}{|c|c|c|c|}
\hline & $\begin{array}{c}\text { All employees } \\
(1)\end{array}$ & $\begin{array}{c}\text { 39-hour workweek } \\
(2)\end{array}$ & $\begin{array}{c}\text { 35-hour workweek } \\
(3)\end{array}$ \\
\hline \hline$\beta_{\tau}^{I}$ & $0.338^{* *}$ & $0.605^{* *}$ & $0.320^{* *}$ \\
$(0.169)$ & $(0.297)$ & $(0.161)$ \\
\hline$\beta_{\tau}^{P}$ & 0.053 & -0.422 & 0.127 \\
$\beta_{\rho}^{I}$ & $(0.163)$ & $(0.303)$ & $(0.217)$ \\
\hline$\beta_{\rho}^{P}$ & -0.618 & -0.434 & $-1.325^{*}$ \\
& $(0.743)$ & $(0.529)$ & $(0.938)$ \\
\hline \hline Tax records variables & $-2.025^{* *}$ & $-1.872^{* *}$ & $-2.341^{* *}$ \\
\hline LFS variables & $(1.007)$ & $(0.942)$ & $(0.913)$ \\
\hline Ybservations & Yes & Yes & Yes \\
\hline
\end{tabular}

Table 4- Elasticities for employees in $\mathbf{3 5}$ and 39-hour firms

Source: ERF survey, Insee, 2003-2006. Notes: standard errors in parentheses. * denotes significance at 10\%, ** significance at $5 \%$ and $* * *$ significance at $1 \%$. Estimation by 2 SLS using instruments I and II. All regressions include time dummies, the position with respect to the 35 -hour arrangement by year, a 5 -th order polynomial of base year gross wages, and variables from tax records and the LFS.

We next present the results for females and males separately in Table 5. The estimates for males are very similar to those for the whole population. For females, the results are imprecise and the elasticities are significant only at $10 \%$. Our main result that gross wages are insentive to marginal payroll taxes but respond to marginal income taxes remains nevertheless valid for both sub-samples. It is worth noting, also, that the elasticity with respect to the marginal income net-of-tax rate is larger for females than for males. This seems to suggest that the behavioral responses come from labor supply decisions. By contrast, wage bargaining may be ruled out as explanation for the response to marginal income net-of-tax rates, since there is no reason why males and females should be considered differently in collective bargaining once their other characteristics are controlled for.

\begin{tabular}{|c|c|c|}
\hline & Females & Males \\
\hline$\beta_{\tau}^{I}$ & $0.606^{*}$ & $0.390^{* * *}$ \\
& $(0.372)$ & $(0.133)$ \\
\hline$\beta_{\tau}^{P}$ & 0.262 & -0.220 \\
& $(0.227)$ & $(0.163)$ \\
\hline$\beta_{\rho}^{I}$ & -0.675 & $-2.678^{* * *}$ \\
\hline$\beta_{\rho}^{P}$ & $(0.750)$ & $(0.786)$ \\
\hline \hline Tax records variables & $-2.357^{*}$ & $-2.20^{* * *}$ \\
\hline LFS variables & $(1.350)$ & $(0.649)$ \\
\hline Observations & Yes & Yes \\
\hline
\end{tabular}

Table 5 - Elasticities for females and males

Source: ERF survey, Insee, 2003-2006. Notes: standard errors in parentheses. * denotes significance at 10\%, ** significance at $5 \%$ and $* * *$ significance at $1 \%$. Estimation by 2 SLS using instruments I and II. All regressions include time dummies, the position with respect to the 35-hour arrangement by year, a 5-th order polynomial of base year gross wages, and variables from tax records and the LFS. 


\section{Conclusion}

In this paper, we estimate the behavioral responses of the gross labor income to marginal and average tax rates of both the income and the payroll tax schedules in France over the period 20032006. We use the extension of income tax credit for low wage earners that took place over this period to indentify the responses to the income tax schedule. We use changes in the schedules of reduction of employers' social security contribution for low paid jobs to identify the responses to the payroll tax schedules. We find a significant elasticity of the gross labor income with respect to the marginal income net-of-tax rate around 0.3. Conversely, we find no significant effect of marginal payroll net-oftax rate. This discrepancy appears robust to different specification and selection. It is in contradiction with a prediction that is common to a large class of models of the labor market, in particular the competitive labor supply framework, which plays a central role in the theoretical literature of optimal income taxation.

We also find a significant elasticity of gross labor income to the average payroll net-of tax rate, which is not significantly different than minus one. Conversely, the elasticity with respect to the average income net-of-tax rate is much weaker and generally not significant. Among the different theories that can account for different behavioral responses to payroll and income taxation, the most plausible one is based on the rigidity of the hourly posted wage, together with labor supply responses to the income tax schedule.

This suggests that the payroll tax schedule may be less distortive than income tax schedule, at least over the short horizon of our study. Another implication is that reduction of employers' social security contributions that play a very important role in France seems to benefit exclusively to the employer, so presumably to the labor demand of low skilled jobs. Moreover, our estimates does not support the view that these programs exacerbated a low-wage trap.

This work can be extended in different directions. A first direction would consider a longer panel of observations to investigate the long run responses to taxation. This in particular would enable to test whether the irresponsiveness of posted wages to payroll taxation is only a short run result or whether the responses of gross wages to payroll taxation in the long run are similar to the responses to income taxation. Another extension is to disentangle the responses we obtain in terms of wage formation, labor demand effects, participations decisions effects and intensive labor supply effects.

\section{References}

Aeberhardt, R. and D. Sraer, 2009, Allégements de cotisations patronales et dynamique salariale, Economie et Statistique, 429-430, 177-189. 
Alvaredo, F. and E. Saez, 2010, The Effects of Payroll Taxes on Earnings: Evidence from Spanish Administrative Earnings Data, UC Berkeley Working Paper (in preparation).

Auten, G. and R. Caroll, 1999, The Effect of Income Tax on Household Income, The Review of Economics and Statistics, 81(4), 681-93.

Bunel, M., F. Gilles, and Y. L'Horty, 2009, Les effets des allégements de cotisations sociales sur l'emploi et les salaires : Une évaluation de la réforme de 2003, Economie et Statistique, 429-430, 77 105.

Bunel, M., F. Gilles, Y. L'Horty, and M. Pauchet, 2008, The impacts of Employer-Paid Payroll taxes reform: an empirical evaluation of the 2003 French policy, CEE working paper.

Blomquist, S. and H. Selin, 2010, Hourly wage rate and taxable income responsiveness to changes in marginal tax rates, Journal of Public Economics, 94(11-12), 878-889.

Cabannes, P-Y, Houdré, C. and Landais, C, 2011, Est-il souhaitable d'augmenter le taux supérieur d'imposition des revenus pour consolider les finances publiques ? Une estimation de l'élasticité du revenu imposable au taux marginal, mimeo.

Feldstein, M., 1995, The Effect of Marginal Tax Rates on Taxable Income: A Panel Study on the 1986 Tax Reform Act, Journal of Political Economy, 103(3), 551-572.

Gruber, J., 1997, The Incidence of Payroll Taxation: Evidence from Chile, Journal of Labor Economics, 15 (3, Part 2), S72-S101.

Gruber, J. and E. Saez, 2002, The elasticity of taxable income: evidence and implications, Journal of Public Economics, 84(1), 1-32.

Hersoug, T., 1984, Union Wage Responses to Tax Changes, Oxford Economic Papers, 36(1), 37-51.

Holmlund and Söderström, 2008, Estimating Dynamic Income Responses to Tax Reforms: Swedish Evidence, Institute for Labour Market Policy Evaluation (IFAU) Working Paper 2008-28 http://www.ifau.se/Upload/pdf/se/2008/wp08-28.pdf

Kramarz, F. and T. Philippon, 2001, The impact of differential payroll tax subsidies on minimum wage employment, Journal of Public Economics, 82(1), 115-146.

Landais, C., Piketty, T. and Saez, E, 2011, Pour une revolution fiscale: un impôt sur le revenu pour le XXIeme siècle, http://www.revolution-fiscale.fr/

Lindsey, L., 1987, Individual taxpayer response to tax cuts: 1982-1984, with the implications for the revenue maximizing tax rate, Journal of Public Economics, 33, 173-206.

Lhommeau, B. and V. Remy, 2009, Les politiques d'allégements ont-elles un effet sur la mobilité salariale des travailleurs à bas salaires ?, Economie et Statistique, 429-430, 21-49.

Lockwood, B. and Manning A., 1993, Wage Setting and the Tax System: Theory and evidences for the United Kingdom, Journal of Public Economics, 52(1), 1-29.

Mirrlees, J.A., 1971, An exploration in the theory of optimal income taxation, Review of Economic Studies, 38, 175-208.

Pissarides, C.A., 2000, Equilibrium Unemployment Theory, Second edition, MIT Press.

Saez, E., 2003, The effect of marginal tax rates on income: a panel study of 'bracket creep', Journal of Public Economics, 87(5-6), 1231-1258.

Saez, E., J. Slemrod, and S. Giertz, 2010, The Elasticity of Taxable Income with Respect to Marginal Tax Rates: A Critical Review, Journal of Economic Literature, Forthcoming.

Saez, E., M. Matsaganis, and P. Tsakloglou, 2010, Earnings determination and taxes: evidence from a cohort based payroll tax reform in Greece, NBER Working Paper 15745. 


\section{Appendix A}

\section{A.1) Proof of Equation (6)}

Combining Equations (4) and (5) leads to:

$$
\frac{\Delta w}{w^{*}}=\beta_{\tau}^{p} \frac{\Delta \tau^{P}}{\tau^{p}}+\beta_{\tau}^{I} \frac{\Delta \tau^{I}}{\tau^{I}}+\frac{\partial W}{\partial R^{P}}\left[\Delta \tau^{P}+\frac{\Delta I^{P}}{w^{*}}\right]+\frac{\partial W}{\partial R^{I}}\left[\rho^{P} \Delta \tau^{I}+\frac{\Delta R^{I}}{w^{*}}\right]
$$

Using $\Delta \rho^{P}=\Delta \tau^{\mathrm{P}}+\left(\Delta R^{\mathrm{P}} / w^{*}\right)$ and $\Delta \rho^{I}+\left(R^{I} / \mathrm{z}^{*}\right)\left(\Delta \rho^{P} / \rho^{P}\right)=\Delta \tau^{\mathrm{I}}+\left(\Delta R^{\mathrm{I}} / \mathrm{z}^{*}\right)$ gives:

$$
\frac{\Delta w}{W^{*}}=\beta_{\tau}^{p} \frac{\Delta \tau^{P}}{\tau^{p}}+\beta_{\tau}^{I} \frac{\Delta \tau^{I}}{\tau^{I}}+\frac{\partial W}{\partial R^{P}} \Delta \rho^{P}+\frac{\partial W}{\partial R^{I}} \rho^{P}\left[\Delta \rho^{I}+\frac{R^{I}}{z^{*}} \frac{\Delta \rho^{P}}{\rho^{P}}\right]
$$

Rearranging terms using Equation (7) gives Equation (6).

\section{A.2) Proof of Equations (5'), (6') and (7')}

Differentiating both sides of (8) gives:

$$
\begin{aligned}
& \frac{\partial W}{\partial \tau^{I}}=\tau^{P} \frac{\partial \Omega}{\partial \tau}+R^{P} \frac{\partial \Omega}{\partial R} \quad \frac{\partial W}{\partial \tau^{P}}=\tau^{I} \frac{\partial \Omega}{\partial \tau} \\
& \frac{\partial W}{\partial R^{I}}=\frac{\partial \Omega}{\partial R} \quad \frac{\partial W}{\partial R^{P}}=\tau^{I} \frac{\partial \Omega}{\partial R}
\end{aligned}
$$

Then, using (5) and (5') gives:

$$
\begin{aligned}
\beta_{\tau}^{P} & =\left(\frac{\tau^{P}}{w} \frac{\partial W}{\partial \tau^{P}}\right)-\tau^{P} \frac{\partial W}{\partial R^{P}}=\left(\frac{\tau^{P} \tau^{I}}{w} \frac{\partial \Omega}{\partial \tau}\right)-\tau^{P} \tau^{I} \frac{\partial \Omega}{\partial R}=\left(\frac{\tau}{w} \frac{\partial \Omega}{\partial \tau}\right)-\tau \frac{\partial \Omega}{\partial R}=\beta_{\tau} \\
\beta_{\tau}^{I} & =\left(\frac{\tau^{I}}{w} \frac{\partial W}{\partial \tau^{I}}\right)-\tau^{I} \rho^{P} \frac{\partial W}{\partial R^{I}}=\frac{\tau^{P} \tau^{I}}{w} \frac{\partial \Omega}{\partial \tau}+\frac{\tau^{I}}{w} R^{P} \frac{\partial \Omega}{\partial R}-\tau^{I} \rho^{P} \frac{\partial \Omega}{\partial R} \\
& =\left(\frac{\tau}{w} \frac{\partial \Omega}{\partial \tau^{P}}\right)-\tau^{I}\left(\tau^{P}+\frac{R^{P}}{w}-\frac{R^{P}}{w}\right) \frac{\partial \Omega}{\partial R}=\left(\frac{\tau}{w} \frac{\partial \Omega}{\partial \tau}\right)-\tau \frac{\partial \Omega}{\partial R}=\beta_{\tau}
\end{aligned}
$$

Using (7) and (7') gives: 


$$
\begin{aligned}
& \beta_{\rho}^{P}=\rho^{P} \frac{\partial W}{\partial R^{P}}+\rho^{P} \frac{R^{I}}{z^{*}} \frac{\partial W}{\partial R^{I}}=\rho^{P}\left(\tau^{I}+\frac{R^{I}}{z^{*}}\right) \frac{\partial \Omega}{\partial R}=\rho^{P} \rho^{I} \frac{\partial \Omega}{\partial R}=\rho \frac{\partial \Omega}{\partial R}=\beta_{\rho} \\
& \beta_{\rho}^{I}=\rho^{P} \rho^{I} \frac{\partial W}{\partial R^{I}}=\rho \frac{\partial \Omega}{\partial R}=\beta_{\rho}
\end{aligned}
$$

\section{A.3) Sign of $\beta_{\tau}$ in Equation (9)}

The first-order condition of the maximization of $U(\tau w+R, w)$ writes: $F(w, \tau, R)=0$, where function $F(., .,$.$) is defined by: F(w, \tau, R) \equiv \tau \cdot U_{1}^{\prime}(\tau w+r, w)+U_{2}^{\prime}(\tau w+r, w)$. Assuming that the second-order condition $F_{w}^{\prime}<0$ holds with a strict inequality (which is the case if for instance $U$ is strictly concave), the implicit function theorem enables us to compute the partial derivatives of function $\Omega(.,$.$) at w^{*}=\Omega(\tau, R)$ through:

$$
\Omega_{\tau}^{\prime}=-\frac{F_{\tau}^{\prime}}{F_{w}^{\prime}}=-\frac{U_{1}^{\prime}+w^{*}\left(\tau \cdot U_{11}^{\prime \prime}+U_{12}^{\prime \prime}\right)}{F_{w}^{\prime}} \text { and } \Omega_{R}^{\prime}=-\frac{F_{R}^{\prime}}{F_{w}^{\prime}}=-\frac{\tau \cdot U_{11}^{\prime \prime}+U_{12}^{\prime \prime}}{F_{w}^{\prime}}
$$

where the partial derivatives of $U$ are computed at $w=w^{*}$ and $c=\tau w^{*}+R$. Applying (5') gives:

$$
\beta_{\tau}=\frac{\tau}{w^{*}}\left(\Omega_{\tau}^{\prime}-w^{*} \Omega_{R}^{\prime}\right)=-\frac{\tau\left(F_{\tau}^{\prime}-w^{*} F_{R}^{\prime}\right)}{w \cdot F_{w}^{\prime}}=-\frac{\tau}{w \cdot F_{w}^{\prime}} \cdot U_{1}^{\prime}
$$

$\beta_{\tau}>0$ then follows the assumption that the objective $U$ is increasing in $c$, i.e. $U_{1}^{\prime}>0$.

\section{A.4) Proof of (9')}

Let us write $F\left(w, \tau^{P}, \tau^{I}, R^{P}, R^{I}\right)=0$ the first-order condition of the maximization of $U\left(\tau^{P} \tau^{I} w+\tau^{I} R^{P}+R^{I}+k\left(\left(1-\tau^{P}\right) w-R^{P}\right), w\right)$, where function $F(., .$.$) is now defined by:$

$$
\begin{aligned}
& F\left(w, \tau^{P}, \tau^{I}, R^{P}, R^{I}\right) \equiv\left(\tau^{P} \cdot \tau^{I}+k\left(1-\tau^{P}\right)\right) \cdot U_{1}^{\prime}\left(\tau^{P} \tau^{I} w+\tau^{I} R^{P}+R^{I}+k\left(\left(1-\tau^{P}\right) w-R^{P}\right), w\right) . \\
& +U_{2}^{\prime}\left(\tau^{P} \tau^{I} w+\tau^{I} R^{P}+R^{I}+k\left(\left(1-\tau^{P}\right) w-R^{P}\right), w\right)
\end{aligned}
$$

Assuming that the second-order condition $F_{w}^{\prime}<0$ holds with a strict inequality (which is the case if for instance $U$ is strictly concave), the implicit function theorem enables us to compute the partial derivatives of function $W(., . ., .$.$) at w^{*}=W\left(\tau^{P}, \tau^{I}, R^{P}, R^{I}\right)$ through: 


$$
\begin{aligned}
& W_{\tau^{P}}^{\prime}=-\frac{F_{\tau^{P}}^{\prime}}{F_{w}^{\prime}}=-\frac{\left(\tau^{I}-k\right) \cdot U_{1}^{\prime}+\left(\tau^{I}-k\right) \cdot w^{*} \cdot\left(\left(\tau^{P} \cdot \tau^{I}+k\left(1-\tau^{P}\right)\right) \cdot U_{11}^{\prime \prime}+U_{12}^{\prime \prime}\right)}{F_{w}^{\prime}} \\
& W_{\tau^{I}}^{\prime}=-\frac{F_{\tau^{I}}^{\prime}}{F_{w}^{\prime}}=-\frac{\tau^{P} \cdot U_{1}^{\prime}+\left(\tau^{P} \cdot w^{*}+R^{P}\right) \cdot\left(\left(\tau^{P} \cdot \tau^{I}+k\left(1-\tau^{P}\right)\right) \cdot U_{11}^{\prime \prime}+U_{12}^{\prime \prime}\right)}{F_{w}^{\prime}} \\
& W_{R^{P}}^{\prime}=-\frac{F_{R^{P}}^{\prime}}{F_{w}^{\prime}}=-\frac{\left(\tau^{I}-k\right) \cdot\left(\left(\tau^{P} \cdot \tau^{I}+k\left(1-\tau^{P}\right)\right) \cdot U_{11}^{\prime \prime}+U_{12}^{\prime \prime}\right)}{F_{w}^{\prime}} \\
& W_{R^{I}}^{\prime}=-\frac{F_{R^{I}}^{\prime}}{F_{w}^{\prime}}=-\frac{\left(\tau^{P} \cdot \tau^{I}+k\left(1-\tau^{P}\right)\right) \cdot U_{11}^{\prime \prime}+U_{12}^{\prime \prime}}{F_{w}^{\prime}}
\end{aligned}
$$

where the various partial derivatives are computed at $w=w^{*}$ and $c=\tau w^{*}+R$. Applying (5) while taking $z^{*}=\tau^{P} w^{*}+R^{P}$ into account leads to:

$$
\begin{aligned}
& \beta_{\tau^{I}}=\frac{\tau^{I}}{w^{*}} \cdot\left(W_{\tau^{I}}^{\prime}-z^{*} \cdot W_{R^{I}}^{\prime}\right)=-\frac{\tau^{I}\left(F_{\tau^{I}}^{\prime}-z^{*} \cdot F_{R^{I}}^{\prime}\right)}{w \cdot F_{w}^{\prime}}=-\frac{\tau^{P} \cdot \tau^{I}}{w \cdot F_{w}^{\prime}} \cdot U_{1}^{\prime}>0 \\
& \beta_{\tau^{P}}=\frac{\tau^{P}}{w^{*}} \cdot\left(W_{\tau^{P}}^{\prime}-w^{*} \cdot W_{R^{P}}^{\prime}\right)=-\frac{\tau^{P}\left(F_{\tau^{P}}^{\prime}-w^{*} F_{R^{P}}^{\prime}\right)}{w \cdot F_{w}^{\prime}}=-\frac{\tau^{P}\left(\tau^{I}-k\right)}{w \cdot F_{w}^{\prime}} \cdot U_{1}^{\prime}=\beta_{\tau^{I}} \cdot\left(1-\frac{k}{\tau^{I}}\right)
\end{aligned}
$$

where the inequalities follow the second-order conditions $F_{w}^{\prime}<0$ and $U_{1}^{\prime}>0$. Applying (7) then gives:

$$
\begin{aligned}
& \beta_{\rho}^{I}=\rho^{P} \cdot \rho^{I} \cdot W_{R^{I}}^{\prime}=-\frac{\rho^{P} \cdot \rho^{I} \cdot\left(\left(\tau^{P} \cdot \tau^{I}+k\left(1-\tau^{P}\right)\right) \cdot U_{11}^{\prime \prime}+U_{12}^{\prime \prime}\right)}{F_{w}^{\prime}} \\
& \beta_{\rho}^{P}=\rho^{P} \cdot\left[W_{R^{P}}^{\prime}+\frac{R^{I}}{Z^{*}} W_{R^{I}}^{\prime}\right]=-\frac{\rho^{P} \cdot\left(\tau^{I}-k+\frac{R^{I}}{z^{*}}\right) \cdot\left(\left(\tau^{P} \cdot \tau^{I}+k\left(1-\tau^{P}\right)\right) \cdot U_{11}^{\prime \prime}+U_{12}^{\prime \prime}\right)}{F_{w}^{\prime}} \\
& =-\frac{\rho^{P} \cdot\left(\rho^{I}-k\right) \cdot\left(\left(\tau^{P} \cdot \tau^{I}+k\left(1-\tau^{P}\right)\right) \cdot U_{11}^{\prime \prime}+U_{12}^{\prime \prime}\right)}{F_{w}^{\prime}}=\beta_{\rho}^{I} \cdot\left(1-\frac{k}{\rho^{I}}\right)
\end{aligned}
$$

Therefore we get (9') as $k<\tau^{I}$ and $k<\rho^{I}$. 


\section{Appendix B: additional empirical results}

Table 6 reproduces the results of the first stage equations, under the specification and method that correspond to the results in Table 2, column 3. Unlike for the other results, we report $\mathrm{T}$ statistics in brackets instead of standard deviation. In bold are estimates of the direct effects of $\Delta \log \bar{\varphi}_{i, t}^{j}$ and $\Delta \log \bar{\varphi}_{i, t}^{j}$ on $\Delta \log \varphi_{i, t}^{j}$

\begin{tabular}{|c|c|c|c|c|}
\hline & $\Delta \log \tau_{i, t}^{I}$ & $\Delta \log \tau_{i, t}^{P}$ & $\Delta \log \rho_{i, t}^{I}$ & $\Delta \log \rho_{i, t}^{P}$ \\
\hline$\Delta \log \bar{\tau}_{i, t}^{I}$ & $\begin{array}{c}\mathbf{0 . 3 5 8}^{* * *} \\
(21.32) \\
\end{array}$ & $\begin{array}{c}-0.093^{* * *} \\
(-6.31) \\
\end{array}$ & $\begin{array}{c}0.024^{* * *} \\
(4.86)\end{array}$ & $\begin{array}{l}-0.003 \\
(-0.59) \\
\end{array}$ \\
\hline$\Delta \log \bar{\tau}_{i, t}^{P}$ & $\begin{array}{c}-0.005 \\
(-0.16)\end{array}$ & $\begin{array}{c}0.479^{* * *} \\
(16.95)\end{array}$ & $\begin{array}{l}0.006 \\
(0.63)\end{array}$ & $\begin{array}{l}0.016 \\
(1.57)\end{array}$ \\
\hline $\begin{aligned} &=I \\
& \Delta \log \tau_{i, t}\end{aligned}$ & $\begin{array}{c}0^{(1.0293}{ }^{*} \\
(1.89)\end{array}$ & $\begin{array}{c}-0.011 \\
(-0.83)\end{array}$ & $\begin{array}{c}0.010^{* *} \\
(2.31)\end{array}$ & $\begin{array}{l}0.005 \\
(0.95)\end{array}$ \\
\hline $\begin{array}{r}=P \\
\Delta \log \tau_{i, t} \\
\end{array}$ & $\begin{array}{r}0.019 \\
(0.57) \\
\end{array}$ & $\begin{array}{c}0^{0.158}{ }^{* * *} \\
(5.38) \\
\end{array}$ & $\begin{array}{l}-0.020 \\
(-2.05) \\
\end{array}$ & $\begin{array}{c}-0.008 \\
(-0.72) \\
\end{array}$ \\
\hline$\Delta \log \bar{\rho}_{i, t}^{I}$ & $\begin{array}{l}0.117 \\
(0.79) \\
\end{array}$ & $\begin{array}{l}-0.037 \\
(-0.28) \\
\end{array}$ & $\begin{array}{c}0.150^{* * * *} \\
(3.44)\end{array}$ & $\begin{array}{c}-0.344^{* * *} \\
(-7.12) \\
\end{array}$ \\
\hline$\Delta \log \bar{\rho}_{i, t}^{P}$ & $\begin{array}{c}-0.321 \\
(-1.45) \\
\end{array}$ & $\begin{array}{c}-0.795^{* * *} \\
(-4.07) \\
\end{array}$ & $\begin{array}{l}-0.079 \\
(-1.22) \\
\end{array}$ & $\begin{array}{l}0.067 \\
(0.93)\end{array}$ \\
\hline$\Delta \log \bar{\rho}_{i, t}^{I}$ & $\begin{array}{l}0.036 \\
(0.29)\end{array}$ & $\begin{array}{l}0.038 \\
(0.35)\end{array}$ & $\begin{array}{c}0.375^{* * * *} \\
(10.49)\end{array}$ & $\begin{array}{c}0.123^{* * *} \\
(3.11)\end{array}$ \\
\hline$\Delta \log \bar{\rho}_{i, t}^{P}$ & $\begin{array}{c}0.430^{*} \\
(1.78) \\
\end{array}$ & $\begin{array}{c}0.461^{* *} \\
(2.16) \\
\end{array}$ & $\begin{array}{c}-0.018 \\
(-0.26) \\
\end{array}$ & $\begin{array}{c}0.472^{* * * *} \\
(6.01)\end{array}$ \\
\hline Tax records variables & Yes & Yes & Yes & Yes \\
\hline LFS variables & Yes & Yes & Yes & Yes \\
\hline Number of individuals & 14311 & 14311 & 14311 & 14311 \\
\hline F Statistic & $13.26^{* *}$ & $14.41^{* * *}$ & $25.59^{* * * *}$ & $15.69 * * *$ \\
\hline
\end{tabular}

Table 6: First-stage regressions

Table 7 displays the complete estimates behind Table 3 . 


\begin{tabular}{|c|c|c|c|c|c|c|}
\hline & $\begin{array}{c}\text { Parameter } \\
\text { Estimate }\end{array}$ & $\begin{array}{l}\text { Standard } \\
\text { Error }\end{array}$ & $\begin{array}{c}\text { Parameter } \\
\text { Estimate }\end{array}$ & $\begin{array}{l}\text { Standard } \\
\text { Error }\end{array}$ & $\begin{array}{r}\text { Parameter } \\
\text { Estimate } \\
\end{array}$ & $\begin{array}{r}\text { Standard } \\
\text { Error } \\
\end{array}$ \\
\hline Intercept & -143.9 & 108.1 & -194.7 & 117.8 & -218.2 & 141.0 \\
\hline$\beta_{\tau}^{I}$ & 0.3135 & 0.149 & 0.352 & 0.160 & 0.338 & 0.170 \\
\hline$\beta_{\tau}^{P}$ & -0.038 & 0.147 & 0.038 & 0.157 & 0.053 & 0.164 \\
\hline$\beta_{\rho}^{I}$ & -0.963 & 0.510 & -0.698 & 0.628 & -0.619 & 0.744 \\
\hline$\beta_{\rho}^{P}$ & -1.527 & 0.460 & -1.595 & 0.483 & -2.025 & 1.008 \\
\hline Time dummy: wave 2004-05 & -0.0007 & 0.0095 & -0.0021 & 0.0103 & 0.0064 & 0.0188 \\
\hline Time dummy: wave 2005-06 & 0.0197 & 0.0119 & 0.0158 & 0.0137 & 0.0259 & 0.0242 \\
\hline \multirow{5}{*}{ Terms of the polynomial of order 5 in $\log w_{i, t-1}$} & 79.46 & 54.35 & 104.09 & 59.29 & 115.78 & 70.35 \\
\hline & -16.90 & 10.79 & -21.60 & 11.78 & -23.93 & 13.86 \\
\hline & 1.747 & 1.059 & 2.188 & 1.156 & 2.422 & 1.350 \\
\hline & -0.088 & 0.051 & -0.109 & 0.056 & -0.120 & 0.065 \\
\hline & 0.0017 & 0.0009 & 0.0021 & 0.0011 & 0.0023 & 0.0012 \\
\hline \multirow{4}{*}{$\begin{array}{l}\text { Age by } 10 \text { years brackets. Reference }=40-49 \text { years } \\
\text { old }\end{array}$} & & & 0.021 & 0.013 & 0.007 & 0.015 \\
\hline & & & 0.021 & 0.010 & 0.017 & 0.011 \\
\hline & & & -0.061 & 0.011 & -0.053 & 0.012 \\
\hline & & & -0.373 & 0.039 & -0.349 & 0.041 \\
\hline$=1$ if women & & & 0.011 & 0.010 & 0.021 & 0.012 \\
\hline$=1$ if women and one more kid & & & -0.109 & 0.033 & -0.103 & 0.035 \\
\hline$=1$ if one more kid since $t-1$ & & & 0.010 & 0.023 & 0.007 & 0.024 \\
\hline$=1$ if women and a child exits & & & -0.045 & 0.032 & -0.046 & 0.035 \\
\hline$=1$ if a kid exits the household since $t-1$ & & & 0.023 & 0.020 & 0.024 & 0.022 \\
\hline$=1$ if women and a child under $18 \mathrm{~m}$. & & & -0.112 & 0.028 & -0.107 & 0.032 \\
\hline$=1$ if women and a child under 3 y.o. & & & 0.023 & 0.027 & 0.014 & 0.029 \\
\hline$=1$ if women and a child under 6 y.o. & & & -0.040 & 0.020 & -0.043 & 0.022 \\
\hline$=1$ if women and a child under 18 y.o & & & 0.015 & 0.015 & 0.018 & 0.016 \\
\hline$=1$ if single individual in the household & & & -0.017 & 0.014 & -0.017 & 0.015 \\
\hline$=1$ if single parent & & & -0.006 & 0.016 & -0.008 & 0.017 \\
\hline$=1$ if couple with kids & & & -0.026 & 0.011 & -0.025 & 0.012 \\
\hline$=1$ if "complex" households & & & -0.030 & 0.023 & -0.028 & 0.024 \\
\hline$=1$ if education level is graduate & & & & & 0.053 & 0.021 \\
\hline$=1$ if education level is college & & & & & 0.031 & 0.018 \\
\hline$=1$ if education level is secondary level & & & & & 0.016 & 0.018 \\
\hline$=1$ if started or professional secondary education & & & & & 0.033 & 0.015 \\
\hline$=1$ if education level is junior high school. & & & & & 0.020 & 0.019 \\
\hline$=1$ if industry $=$ manufacturing & & & & & 0.009 & 0.013 \\
\hline$=1$ if industry $=$ agriculture & & & & & 0.012 & 0.031 \\
\hline$=1$ if industry $=$ construction & & & & & 0.006 & 0.018 \\
\hline$=1$ if industry $=$ energy & & & & & 0.006 & 0.032 \\
\hline$=1$ if industry in education or social services & & & & & -0.005 & 0.015 \\
\hline$=1$ if industry= retail and repair & & & & & -0.004 & 0.011 \\
\hline$=1$ if self-employed & & & & & -0.016 & 0.041 \\
\hline$=1$ if engineers, managers and professionals & & & & & -0.012 & 0.016 \\
\hline$=1$ if less than 10 employees in the firm & & & & & -0.001 & 0.013 \\
\hline$=1$ if between 10 and 19 employees & & & & & 0.001 & 0.017 \\
\hline$=1$ if 35 hours firm and wave 2003-04 & & & & & -0.00237 & 0.02894 \\
\hline$=1$ if 35 hours firm and wave $2004-05$ & & & & & -0.02015 & 0.02454 \\
\hline$=1$ if 35 hours firm and wave $2005-06$ & & & & & -0.02286 & 0.01698 \\
\hline$=1$ if job tenure is less than 1 year & & & & & -0.05594 & 0.06155 \\
\hline$=1$ if job tenure is between 1 and 5 years & & & & & -0.17074 & 0.05847 \\
\hline$=1$ if job tenure is between 5 and 10 years & & & & & -0.14757 & 0.06155 \\
\hline$=1$ if job tenure is more than 10 years & & & & & -0.15195 & 0.06317 \\
\hline
\end{tabular}

Table 7: complete results of Table 3 